\title{
Front Matter: Volume 8319
}

, "Front Matter: Volume 8319," Proc. SPIE 8319, Medical Imaging 2012: Advanced PACS-based Imaging Informatics and Therapeutic Applications, 831901 (16 February 2012); doi: 10.1117/12.930508

SPIE. Event: SPIE Medical Imaging, 2012, San Diego, California, United States 


\title{
Medical Imaging 2012
}

\section{Advanced PACS-based Imaging Informatics and Therapeutic Applications}

\author{
William W. Boonn \\ Brent J. Liu \\ Editors
}

\section{8-9 February 2012 \\ San Diego, California, United States}

Sponsored by

SPIE

Cosponsored by

Agilent Technologies • Diamond SA (Switzerland) - DQE Instruments, Inc. (Canada)

eMagin (United States) • Isuzu Glass Co., Ltd. (Japan) • Medtronic. Inc. • Ocean Thin Films, Inc. (United States)

Cooperating Organizations

AAPM-American Association of Physicists in Medicine (United States) • CARS—Computer Assisted Radiology and Surgery (Germany) • Medical Image Perception Society (United States) - Radiological Society of North America (United States) - APS_American Physiological Society (United States) - The DICOM Standards Committee (United States) • Society for Imaging Informatics in Medicine (United States) • The Society for Imaging Science and Technology • World Molecular Imaging Society

Published by

SPIE

Volume 8319 
The papers included in this volume were part of the technical conference cited on the cover and title page. Papers were selected and subject to review by the editors and conference program committee. Some conference presentations may not be available for publication. The papers published in these proceedings reflect the work and thoughts of the authors and are published herein as submitted. The publisher is not responsible for the validity of the information or for any outcomes resulting from reliance thereon.

Please use the following format to cite material from this book:

Author(s), "Title of Paper," in Medical Imaging 2012: Advanced PACS-based Imaging Informatics and Therapeutic Applications, edited by William W. Boonn, Brent J. Liu, Proceedings of SPIE Vol. 8319 (SPIE, Bellingham, WA, 2012) Article CID Number.

ISSN 1605-7422

ISBN 9780819489685

Published by

SPIE

P.O. Box 10, Bellingham, Washington 98227-0010 USA

Telephone +1 3606763290 (Pacific Time) · Fax +1 3606471445

SPIE.org

Copyright (C) 2012, Society of Photo-Optical Instrumentation Engineers.

Copying of material in this book for internal or personal use, or for the internal or personal use of specific clients, beyond the fair use provisions granted by the U.S. Copyright Law is authorized by SPIE subject to payment of copying fees. The Transactional Reporting Service base fee for this volume is $\$ 18.00$ per article (or portion thereof), which should be paid directly to the Copyright Clearance Center (CCC), 222 Rosewood Drive, Danvers, MA 01923. Payment may also be made electronically through CCC Online at copyright.com. Other copying for republication, resale, advertising or promotion, or any form of systematic or multiple reproduction of any material in this book is prohibited except with permission in writing from the publisher. The CCC fee code is 1605 $7422 / 12 / \$ 18.00$.

Printed in the United States of America.

Publication of record for individual papers is online in the SPIE Digital Library.

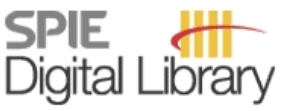

SPIEDigitallibrary.org

Paper Numbering: Proceedings of SPIE follow an e-First publication model, with papers published first online and then in print and on CD-ROM. Papers are published as they are submitted and meet publication criteria. A unique, consistent, permanent citation identifier (CID) number is assigned to each article at the time of the first publication. Utilization of CIDs allows articles to be fully citable as soon as they are published online, and connects the same identifier to all online, print, and electronic versions of the publication. SPIE uses a six-digit CID article numbering system in which:

- The first four digits correspond to the SPIE volume number.

- The last two digits indicate publication order within the volume using a Base 36 numbering system employing both numerals and letters. These two-number sets start with $00,01,02,03,04$, $05,06,07,08,09,0 A, 0 B \ldots 0 Z$, followed by 10-1Z, 20-2Z, etc.

The CID number appears on each page of the manuscript. The complete citation is used on the first page, and an abbreviated version on subsequent pages. Numbers in the index correspond to the last two digits of the six-digit CID number. 


\section{Contents}

ix Conference Committee

xi Reflections on 30 years of PACS [8319-2] (Abstract Only)

J. Honeyman-Buck, Society for Imaging Informatics in Medic ine (United States)

xiii Medical imaging, PACS, and imaging informatics: a personal perspective [8319-3]

(Abstract Only)

H. K. Huang, Univ. of Southem Califomia (United States)

XV Fortieth a nniversary of SPIE Medical Imaging meeting (Ovenview Paper)

R. M. Nishikawa, Carl J . Vybomy Translation Lab. for Brea st Imaging Research, The Univ. of

Chic ago (United States)

\section{CLOUD AND MOBILE COMPUING}

831907 CEDIMS: cloud ethical DICOM image Mojette storage [8319-06]

J. Guédon, IRCCyN, CNRS, Univ. de Nantes (France); P. Evenou, IRCCyN, CNRS, Univ. de Nantes (France) and Fizians (France); P. Tervé, Keosys (France); S. Da vid, Fizians (France); J. Béranger, Keosys (France)

831908 A cloud-based medical image repository [8319-07]

A. J. Maeder, B. M. Planitz, D. El Rifai, Univ. of Westem Sydney (Australia)

831909 Performance evaluation of a visual display calibration algonithm for iPad [8319-08]

L De Paepe, P. De Bock, Barco N.V. (Belgium); O. Vanovemeire, AZGroeninge Hospital

(Belgium); T. Kimpe, Barco N.V. (Belgium)

8319 OA A comprehensive framework for quality assurance in clinical trials [8319-09]

O. El Gazzar, M. Onken, M. Eichelberg, A. Hein, OFFIS e.V. (Germany); E. Kotter, Univ. Hospital Freiburg (Gemany)

\section{DATA MINING I}

8319 OB Efficient similanity search on 3D bounding box annotations [8319-10]

H.-P. Kriegel, M. Petri, M. Schubert, M. Shekelyan, M. Stockerl, Lud wig-Maximilians-Univ. München (Gemany)

8319 OC Implementation and application of an interactive user-friendly validation software for RADIANCE [8319-11]

A. Sundaram, Univ. of Pennsylvania (United States); W. W. Boonn, W. Kim, T. S. Cook, Hospital of the Univ. of Pennsylvania (United States) 
8319 OD Linking DICOM pixel data with radiology reports using automatic semantic annotation [8319-12]

S. D. Pathak, Mic rosoft Corp. (United States); W. Kim, The Hospital of the Univ. of Pennsylvania (United States); I. Munasinghe, A. Criminisi, Microsoft Research Cambridge (United Kingdom); S. White, K. Sid diqui, Mic rosoft Corp. (United States)

8319 OE Medical image retrieval system using multiple features from 3D ROls [8319-13] H. Lu, W. Wang, Q. Lia o, G. Zhang, Z Zhou, Fourth Military Medical Univ. (China)

8319 OF Multi-scale visual words for hierarchical medical image categorisation [8319-14] D. Markonis, A. G. Seco de Herrera, I. Eggel, H. Müller, HES-SO (Switzerland)

\section{PACS/SYSTEMS INTEGRATION}

8319 OG Lesion companison of multiple sclerosis in hispanic and caucasian patients utilizing an imaging informatics-based efoldersystem [8319-15]

K. Ma, J. Femand ez, L. Amezc ua, A. Lemer, M. Shiroishi, B. Lu, The Univ. of Southem Califomia (United States)

$8319 \mathrm{OH}$ Automating PACS quality control with the Vanderbilt image processing enterprise resource [8319-16]

M. L Esparza, E. B. Welch, Vanderbilt Univ. (United States); B. A. Landman, Vanderbilt Univ. (United States) and J ohns Hopkins Univ. (United States)

8319 ol Design of e-Science platfom for biomedical imaging research cross multiple academic institutions and hospitals [8319-17]

J. Zhang, Shanghai Institute of Technic al Physics (China) and Shanghai I iaotong Univ. (China); K. Zhang, Y. Yang, T. Ling, T. Wang, M. Wang, Shang hai Institute of Technic al Physic S (China); H. Hu, X. Xu, Shanghai J ia otong Univ. (China)

8319 0] Managing and querying whole slide images [8319-18]

F. Wang, T. W. Oh, Emory Univ. (United States); C. Vergara-Niedermayr, The Cancer Institute of New J ersey (United Sta tes); T. Kurc, J. Saltz, Emory Univ. (United Sta tes)

8319 OK Synchronized slice viewing of similar image series [8319-19]

S. Ali, HES-SO (Switzerland) and Univ. de Bourgogne (France); A. Foncubierta, HES-SO (Switzerland); A. Depeursinge, HES-SO (Switzerland) and Univ. Hospitals and Univ. of Geneva (Switzerland); F. Meriaudeau, Univ. de Bourgogne (France); O. Ratib, Univ. Hospitals of Geneva (Switzerland); H. Müller, HES-SO (Switzerland) and Univ. Hospitals and Univ. of Geneva (Switzerland)

$8319 \mathrm{OL}$ The impact of skull bone intensity on the quality of compressed CTneuro images [8319-20] I. Kowa lik-Urbaniak, E. R. Vrsc ay, Z Wang, Univ. of Waterloo (Canada); C. Cavaro-Menard, Univ. de Angers (France); D. Koff, McMaster Univ. (Canada); B. Wallace, Agfa Healthcare, Inc. (Canada); B. Obara, Univ. of Oxford (United Kingdom) 
8319 OM Retrieving biomedical images through content-based leaming from examples using fine granularity [8319-21]

H. J iang, The Univ. of Hong Kong (Hong Kong, China); S. Xu, Oak Ridge National Lab. (United States); F. C. M. Lau, The Univ. of Hong Kong (Hong Kong, China)

8319 ON Comparative analysis of semantic localization accuracies between adult and pediatric DICOM CTimages [8319-22]

D. Robertson, Microsoft Research Cambridge (United Kingdom); S. D. Pathak, Microsoft Corp. (United States); A. Criminisi, Mic ro soft Research Cambridge (United Kingdom);

S. White, Mic rosoft Corp. (United States); D. Haynor, Univ. of Washington (United States);

O. Chen, K. Sid diqui, Mic rosoft Corp. (United States)

831900 Computer-assisted radiation treatment planning system for determination of beam directions based on similar cases in a database forstereotactic body radiotherapy [8319-23]

T. Magome, Kyushu Univ. (J apan) and J apan Society for the Promotion of Science (J a pan); H. Arimura, Y. Shioyama, A. Mizoguc hi, C. Tokunaga, K. Naka mura, H. Honda, M. O hki, F. Toyofuku, H. Hirata, Kyushu Univ. (J apan)

8319 OP Creating a classification of image types in the medical literature for visual categonization [8319-24]

H. Müller, HES-SO (Switzerland) and Univ. Hospita Is and Univ. of Geneva (Switzerland); J. Kalpathy-Cramer, Harva rd Univ. (United States); D. Demner-Fushman, S. Antani, National Library of Medic ine (United States)

8319 0Q Data mining DICOM RT objects for quality control in radiation oncology [8319-25] R. R. Deshpande, The Univ. of So uthem Califomia (United States); J. DeMarc o, D. Low, Univ. of Ca lifo mia, Los Angeles (United States); A. H. Le, Univ. of Pittsb urgh (United States); B. J . Liu, The Univ. of Southem Califomia (United States)

\section{THERAPY}

8319 OR Web-based doc umentation system with exchange of DICOM RT for multicenter c linical studies in particle therapy [8319-26]

K. A. Kessel, Heidelberg Univ. Hospital (Gemany); N. Bougatf, Heidelberg Univ. Hospital (Germany) and Heilbronn Univ. (Germany); C. Bohn, U. Engelmann, CHIப G mbH (Gemany); D. Oetzel, Heidelberg Univ. Hospital (Germany); R. Bendl, Heilbronn Univ. (Gemany); J. Debus, S. E. Combs, Heidelberg Univ. Hospital (Germany)

8319 OS Utilization of DICOM multi-frame objects for integrating kinetic and kinematic data with raw videos in movement analysis of wheel-chair users to minimize shoulder pain [8319-27] R. R. Deshpande, H. Li, The Univ. of Southem Califomia (United States); P. Requejo, Rancho Los Amigos National Reha bilitation Ctr. (United States); S. Mc Nitt-Gray, The Univ. of Southem Califomia (United States); P. Ruparel, Rancho Los Amigos National Reha bilitation Ctr. (United States); B. J . Lu, The Univ. of So uthem Califomia (United States) 
8319 0T The peer review system (PRS) for quality assurance and treatment improvement in radiation therapy [8319-28]

A. H. T. Le, Univ. of Pittsb urgh Medic al Ctr. (United States) and Univ. of Florida (United States);

R. Kapoor, J . R. Palta, Univ. of Florida (United States)

8319 OU A multimedia comprehensive informatics system with decision support tools for a multi-site collaboration research of stroke rehabilitation [8319-29]

X. Wang, J. Doc umet, K. A. Gamison, C. J. Winstein, B. Lu, The Univ. of Southem Ca lifomia (United States)

8319 0V An imaging informatics-based ePR (electronic patient record) system for providing decision support in evaluating dose optimization in stroke rehabilitation [8319-30]

B. J . Lu, C. Winstein, X. Wang, M. Konersman, C. Martinez, N. Schweighofer, The Univ. of Southem Califomia (United States)

8319 0W A web-based electronic patient record (ePR) system for data integration in movement analysis research on wheel-chair users to minimize shoulder pain [8319-31]

R. R. Deshpande, The Univ. of Southem Califomia (United States); P. Requejo, Rancho Los Amigos National Rehabilitation Ctr. (United States); E. Sutisna, X. Wang, M. Liu, S. McNitt-Gray, The Univ. of So uthem Califomia (United States); P. Ruparel, Rancho Los Amigos National Rehabilitation Ctr. (United States); B. J . Lu, The Univ. of So uthem Califomia (United States)

\section{POSTER SESSION}

8319 0X Creating a semantic lesion database for computer-aided MR mammography [8319-32] X. Wang, Sunnybrook Research Institute (Canada); A. Martel, Sunnybrook Research Institute (Canada) and Univ. of Toronto (Canada)

8319 oY Teleradiology network system using the web medical image conference system with a new information sec urity solution [8319-33]

H. Sa toh, Tokyo Health Care Univ. (J apan); N. Niki, Univ. of Tokushima (J apan); K. Eguchi, Teikyo Univ. (Japan); H. Ohmatsu, M. Kusumoto, M. Kaneko, R. Kakinuma, N. Moriyama, National CancerCtr. (Japan)

$83190 Z$ A comparison of image communication protocols in e-science platform for biomedical imaging research and applic ations [8319-34]

T. Wang, Y. Yang, Shanghai Institute of Technical Physics (China); H. Hu, Shanghai J ia o Tong Univ. (China); J . Zhang, Shangha i Institute of Technical Physic S (China)

831910 Semantic extraction and processing of medical records for patient-oriented visual index [8319-35]

W. Zheng, W. Dong, X. Chen, J. Zhang, Shanghai Institute of Tec hnical Physics (China)

831911 A new approach of building 3D visualization framework for multimodal medical images display and computed assisted diagnosis [8319-36]

Z L̇, Shanghai Institute of Technical Physics (China) and Henan Univ. of Science and Technology (China); J. Sun, J. Zhang, Shanghai Institute of Tec hnical Physics (C hina) 
831912 MedCast a disc ussion support system for cooperative work (Cum Laude Poster Award) [8319-37]

R. A. Moreno, Univ. of São Paulo Medical School (Brazil); V. Lima, I. Lopes, CPqD Foundation (Brazil); M. A. Gutierrez, Univ. of São Paulo Medical School (Brazil)

831913 A computer-aided detection (CAD) system with a 3D algonithm for small ac ute intracranial hemonhage [8319-38]

X. Wang, J. Femandez, R. Deshpande, J. K. Lee, The Univ. of Southem Ca lifomia (United States); T. Chan, The Univ. of Hong Kong (Hong Kong, C hina); B. Lu, The Univ. of Southem Califomia (United States)

Author Index 
Proc. of SPIE Vol. $8319831901-8$

Downloaded From: https://www.spiedigitallibrary.org/conference-proceedings-of-spie on 26 Apr 2023 Terms of Use: https://www.spiedigitallibrary.org/terms-of-use 


\title{
Conference Committee
}

\author{
Symposium Chairs
}

Joseph M. Reinhardt, The University of lowa (United States)

Nico Karssemeijer, Radboud University Nijmegen Medical Centre (Netherlands)

Conference Chairs

William W. Boonn, The University of Pennsylvania Health System (United States)

Brent J. Liu, The University of Southern California (United States)

Program Committee

James Chen, University of California, San Diego (United States)

Janice C. Honeyman-Buck, University of Florida (United States)

Steven C. Horii, The University of Pennsylvania Health System (United States)

Woojin Kim, The University of Pennsylvania Health System (United States)

Maria Y. Law, The Hong Kong Polytechnic University (Hong Kong, China)

Heinz U. Lemke, Computer Assisted Radiology and Surgery (Germany)

Khan M. Siddiqui, Microsoft Corporation (United States)

Eliot L. Siegel, University of Maryland Medical Center (United States)

John B. Strauss, Microsoft Corporation (United States)

Wyatt Tellis, University of California, San Francisco (United States)

Jianguo Zhang, Shanghai Institute of Technical Physics (China)

Stefan L. Zimmerman, The Johns Hopkins University (United States)

\section{Session Chairs}

1 PACS 30th Anniversary Session

Heinz U. Lemke, Computer Assisted Radiology and Surgery (Germany)

2 Cloud and Mobile Computing

Jianguo Zhang, Shanghai Institute of Technical Physics (China)

3 Data Mining I

Janice C. Honeyman-Buck, University of Florida (United States)

$4 \quad$ PACS/Systems Integration

Brent J. Liu, The University of Southern California (United States) 
5 Data Mining II

Maria Y. Law, The Hong Kong Polytechnic University (Hong Kong, China)

6 Therapy

John B. Strauss, Microsoft Corporation (United States) 


\title{
Reflections on 30 Years of PACS
}

\author{
J. Honeyman-Buck \\ JDI, Society for Imaging Informatics in Medicine, \\ 508 Bramble Fern Ave, DeLand, F1 32720
}

\section{INTRODUCTION}

The papers selected for discussion here are just a small subset of the excellent work of these early innovators. The 1982 volume is an interesting read for all of us active in imaging informatics and in PACS. This presentation will look at early predictions and where we are now in 2012.

\section{EARLY VISIONARIES}

A preliminary review of the papers published in 1982 show us the remarkable forethought on the part of the authors. In many cases, their ideas lead to the PACS or Medical Imaging Informatics we know today.

\subsection{Data Storage Requirements - Sam Dwyer, III - University of Kansas ${ }^{1}$}

Sam Dwyer and his colleagues at the University of Kansas estimated the volume of digital data that would need to be stored in a diagnostic imaging department serving a 614 bed hospital. in 1982. His conclusions were that the cost of digital storage was $75 \%$ of the cost of analog and that it was feasible to store this volume. His projections for future storage requirements were remarkably accurate.

\subsection{Digital PACS requirements - Andre J. Duerinckx ${ }^{2}$}

Andre J. Duerinckx argued that every radiology department has a PACS in the form of a centralized analog film file room managing both film and video raster film recordings used for imaging of digital diagnostic images. The challenge was to develop the technology for a digital PACS. His requirements list of technologies were right on track.

\subsection{Benefits of PACS - Dr. Edward V. Staab, University of North Carolina ${ }^{3}$}

This early visionary believed that PACS would solve many of the problems in radiology arising from the rapidly increasing proliferation of imaging devices and the increasing numbers of subspecialties in radiology that hampered easy communication among radiologists. His list of advantages for digital PACS were remarkably accurate in time when many of the technologies required were not yet available.

\section{IMAGE PROCESSING}

Image processing was just starting to be investigated in 1982, but computing power was limited so researchers proposed different ways to manage the problem.

\subsection{Overnight multi-planar reformatting - Michael Rhodes ${ }^{4}$}

Michael Rhodes described network image processing for CT scanners where one of the options was to perform MultiPlanar reformats on the computer overnight when the computers were less likely to be used. 
3.2 Proposed requirements for an image processing system - G.Q. Maquire, Jr. ${ }^{5}$

G.Q. Maguire, Jr, defines the image processing requirements with a proposed integrated systems approach. The problems reported at the time were the extremely long length of time it took to transfer data to a computer for viewing and when the data reside on tape, the length of time is even longer.

\section{PACS AND TELERADIOLOGY}

\subsection{PACS Architectures - proposed by D. Meyer-Ebrect ${ }^{6}$ and Cliff Reader ${ }^{7}$}

Architectures for PACS were proposed by several authors.

\subsection{Teleradiology - proposed by F.L. Skinner ${ }^{8}$ and Will Rasmussen ${ }^{9}$}

Both authors reported on prototype systems.

\subsection{Prototype PACS Samuel J. Dwyer III ${ }^{10}$ and B.G. Thompson ${ }^{11}$}

Authors reported on prototype PACS being built at the University of Kansas and the University of North Carolina.

\section{References}

[1] Dwyer, S. J. III, Templeton, A. W., Martin N. L., Cook L. T., Lee, K. R., Levine, E., Batnitzky, S., Preson, D.F., Rosenthal, S.J., Price, H.I., Anderson, W.H., Tarlton, M.A., Faszold, S., "Cost of managing digital diagnostic imagines for a 614 bed hospital", Proceedings of SPIE Picture Archiving and Communication Systems, 318(1), 3-8 (1982).

[2] Duerinckx, A. J., Pisa, E. J., "Filmless picture archiving and communication in diagnostic radiology", Proceedings of SPIE Picture Archiving and Communication Systems, 318(1), 9-18 (1982).

[3] Staab, E.V., Anderson, D.J., Chaney, E.L., Delany, D.J., DiBianca, F.A., Gulford, W.B., Jaques, P.F., Johnston, R.E., McCartney, W.H., Pizer, S.M., Scatliff, J.H., Thompson, B.G., Washburn, D.B., "Medical image communication system: plan, management and intial experience in prototype at the University of North Carolina", Proceedings of SPIE Picture Archiving and Communication Systems, 318(1), 19-22 (1982).

[4] Rhodes, M.L., Glenn, W.V., Jr., Azzawi,Y., Brewster, R.B., Rothman, S.L.G., "Network image processing for computer tomography (CT) scanners: report on clinical trial sites", Proceedings of SPIE Picture Archiving and Communication Systems, 318(1), 102-109 (1982).

[5] Maguire, G.Q., Jr., Zeleznik, M.P., Horii, S.C., Schimpf, J.H., Noz, M.E., "Image processing requirements in hospitals and an integrated systems approach", Proceedings of SPIE Picture Archiving and Communication Systems, 318(1), 206-213 (1982).

[6] Meyer-Ebrect, D., Bohring, D., Grewer, R., Monnich, K.J., Schmidt, J., Wendler TH., "Hierarchical approach to distributed picture information systems", Proceedings of SPIE Picture Archiving and Communication Systems, 318(1), 112-116 (1982).

[7] Reader, C., Nitteberg, A., “ Desgn criteria for networked image analysis system”, Proceedings of SPIE Picture Archiving and Communication Systems, 318(1), 143-150 (1982).

[8] Skinner, F.L., Cerva, J., Kerlin, B., Millstone, T., "The teleradiology field demonstration" Proceedings of SPIE Picture Archiving and Communication Systems, 318(1), 168-173 (1982).

[9] Rasmussen, W., Stevens, I. "Teleradiology via the naval remote medical diagnosis system (RMDS)". Proceedings of SPIE Picture Archiving and Communication Systems, 318(1), 174-181 (1982).

[10] Dwyer, S.J., III, Templeton, A.W., Anderson, W.H., Tariton, M.A., Hensley, K.S., Lee, K.R., Preston, D.F., Batnitzky, S., Levine, E., Rosenthal, S.J., Martin, N.L., Cook, L.T., "Salient characteristics of a distributed diagnostic imaging management system for a radiology department", Proceedings of SPIE Picture Archiving and Communication Systems, 318(1), 194-204 (1982).

[11] Thompson, B.G., Anderson, D.J., Chaney, E.L., Delany, D.J., DiBianca, F.A., Guilford, W.B., Jaques, P.F., Johnston, R.E., McCartney, W.H., Pizer, S.M., Scatliff, J.H., Staab, E.V., Washburn, D.B., "Medical image communicaitons system: expansion from a prototype at the University of North Carolina", Proceedings of SPIE Picture Archiving and Communication Systems, 318(1), 214 (1982). 


\title{
Medical Imaging, PACS and Imaging Informatics - A Personal Perspective
}

\author{
H. K. Huang ${ }^{\mathrm{a}}$ \\ ${ }^{a}$ Image Processing and Informatics Laboratory, University of Southern California, 734 W Adams \\ Blvd., Los Angeles, CA 90089
}

From my perspective, the development of medical imaging informatics research at IPILab (Imaging Processing and Informatics) has been incubated and evolved gradually through the past 40 years. The first 10 years from the early 70 s to the early 80s was at the National Biomedical Research Foundation (NBR), Georgetown University, Washington D.C. During this period of time, medical imaging input devices, user interface, storage and computing methods were developed, which allowed hardcopy and video images to be converted to digital format, stored, processed and communicated. The list of inventions included the FIDAC (Film Input to Digital Automatic Computer (DAC)) [1], SPIDAC (Specimen Input to DAC) [2], VIDIAC (Vidicon Input to DAC), and DRIDAC (Drum Input to DAC) as well as the MACDAC (Man Machine Communication with DAC) and the IBM 360/44 computer (Figure 1). [3] In addition, the ACTA (Automatic Computerized Transverse Axial) CT scanner, the first whole body CT scanner, could acquire sectional images from patients and animals (Figure 2). [4]
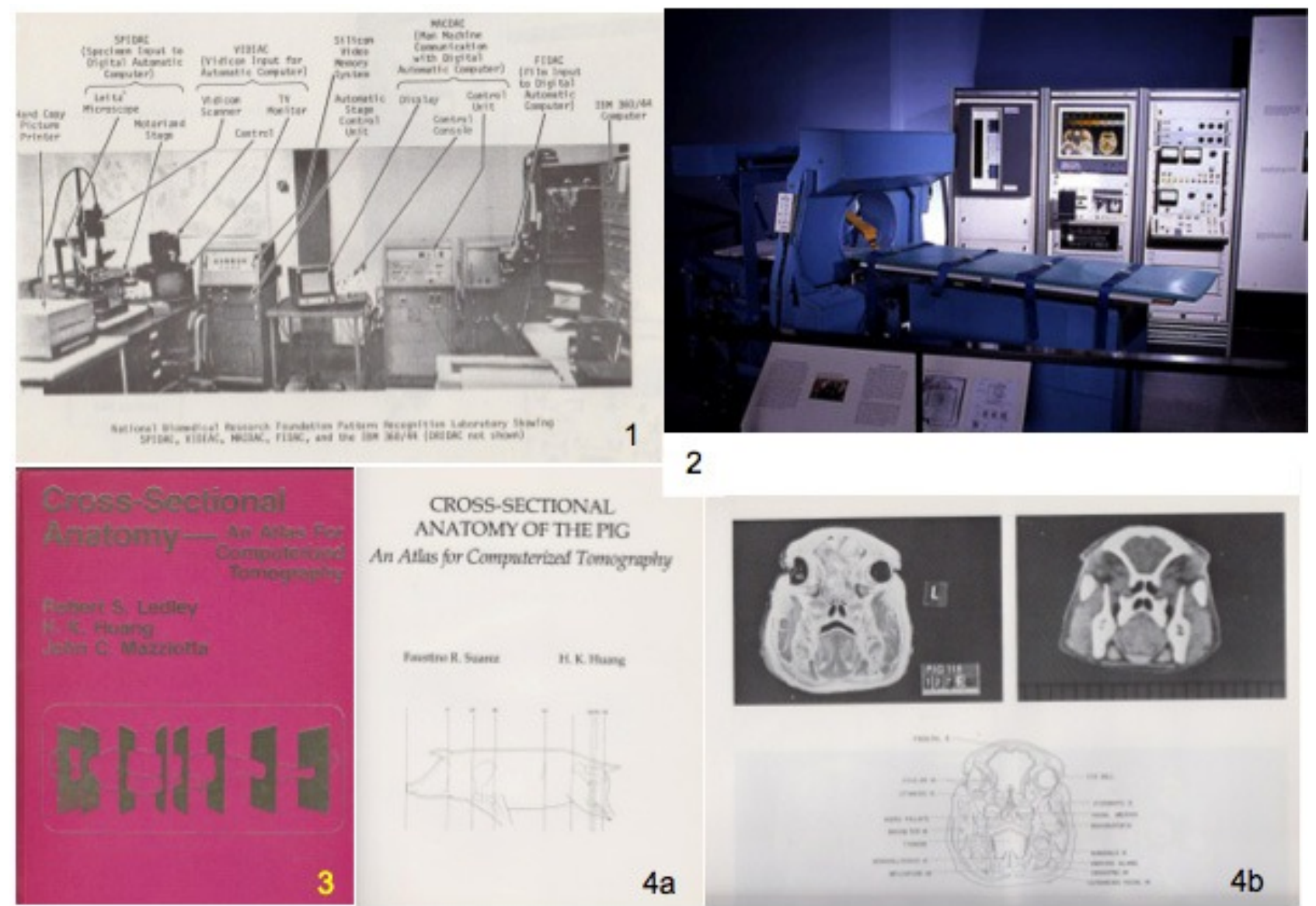

Fig 1, 2, 3, 4a, 4b: Top, Lt to Rt: Pattern Recognition Lab, at NBR, The whole body ACTA Scanner; Bottom, Lt to Mid and Rt: Cross-section Anatomy, Pig Anatomy: A frozen section, CT image, and anatomical drawing 
With these medical imaging devices as well as storage, display and computing subsystems, softcopy medical images became possible [5], in addition to visualization and manipulation of 2-D, 3-D and 4-D human and animal anatomy (Figures 3, 4a, and 4b). [6, 7]

In the past ten years, I retired from the University of California, and assumed my current positions at USC (2000present) to establish the Imaging Processing and Information Laboratory (IPI Lab, Figure 7a, b), as well as at the Hong Kong Polytechnic University (2000-2010) to plan and design the PACS Lab, and to work on the total filmless healthcare delivery system in Hong Kong under the Hong Kong Hospital Authority auspices [9]. During the past ten years, the trends of medical imaging informatics research have shifted gradually from pure radiological diagnosis to medical imaging informatics-based diagnosis and treatment including surgery and radiation therapy and other clinical applications, as well as to embrace the development of health care delivery system.

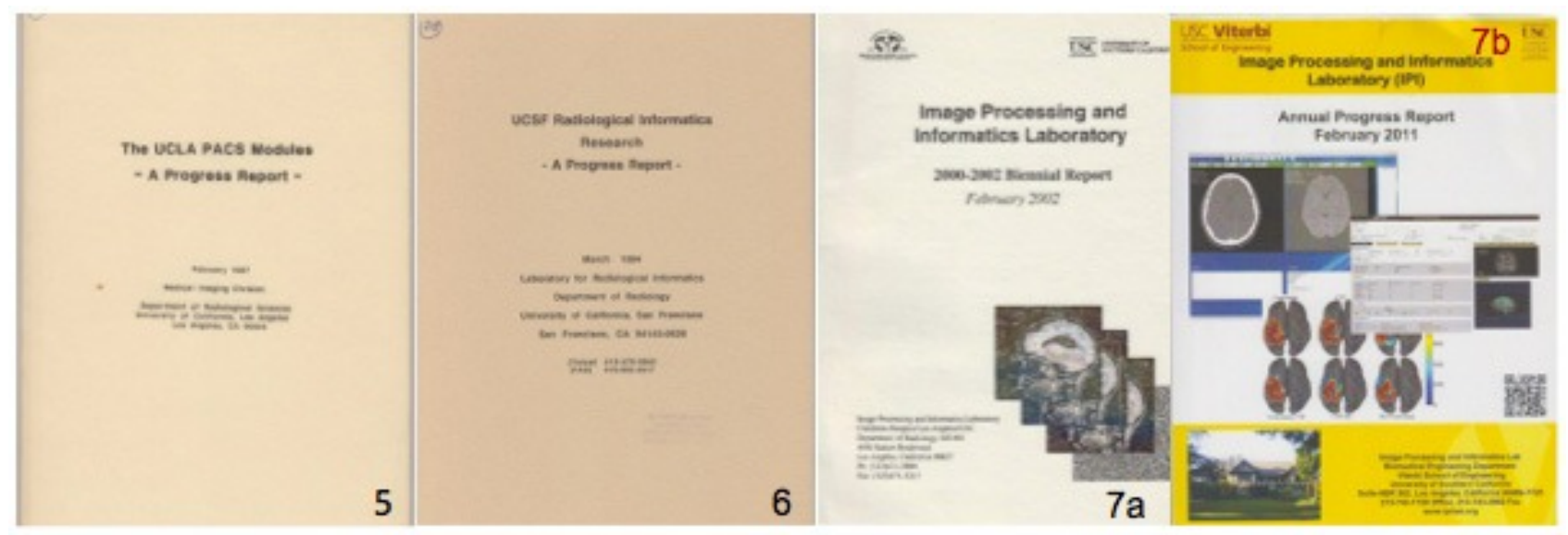

Figures 5, 6, 7a, b. Left to Right: 5. UCLA (1987), 6. UCSF (1994), 7a, b USC (2000-02), USC (2010) Annual Reports

\section{REFERENCES}

[1] Ledley RS, Golab TJ, et al, FIDAC - Film Input to Digital Automatic Computer), Pattern Recognition, 3:123, 1971.

[2] Ledley RS, Huang HK, et al, SPIDAC - Specimen input to digital automatic computer, AFIPS, 42, 489, 1973.

[3] Ledley RS, Huang HK, et al, Pattern Recognition in Clinical Care, Engineers in Clinical Medicine, V.1, Ed. Apter JT, Point Lobos Press Publishers. 160-210, 1974

[4] Ledley RS, Di Chiro G, et al, Computerized transaxial x-ray tomography of the human body Science 1974;186(4160):207-212, 1974.

[5] Huang HK, Ledley RS. Three-dimensional image reconstruction from in vivo consecutive transverse axial sections Comput Biol Med , 5(3):165-170, 1975.

[6] Ledley, R., Huang, HK and Mazziotta, JC, Cross-Sectional Anatomy: An Atlas for Computerized Tomography. Baltimore MD: Williams and Wilkins Co, 1977.

[7] Suarez F, H.K. Huang. Cross-Sectional Anatomy of the Pig. University of Iowa, Iowa City, Iowa. 1982.

[8] Ledley, RS. Wikipedia, the free encyclopedia, 2012.

[9] Huang HK. Consultancy Study on Total Filmless Operation for HA Healthcare Delivery, Internal Report, Hong Kong Hospital Authority, Aug, 2010. 


\title{
Fortieth Anniversary of SPIE Medical Imaging Meeting
}

\author{
Robert M. Nishikawa* \\ Carl J. Vyborny Translation Laboratory for Breast Imaging Research \\ Department of Radiology, and the Committee on Medical Physics, The University of Chicago, 5841 \\ S. Maryland Ave. MC-2026, Chicago, IL 60637
}

This meeting marked the $40^{\text {th }}$ year from the first SPIE Medical Imaging meeting. This paper presents a brief summary of the 40-year history of the meeting, with an emphasis on the Physics Conference. That is, when the meeting split into multiple conferences, data are presented mostly for the Physics conference only.

The first conference was held in 1972 in Chicago and it was called: Application of Optical Instrumentation in Medicine.

\begin{abstract}
"We have endeavored, by way of the seminar, to provide a communication link between those with expertise in the various technologies associated with image forming devices and those in the medical field who rely on the fruits of these technologies for many of their diagnostic tools...there is a genuine interest among those in the medical field for a better understanding of the fundamental technology of imaging systems." William C. Zarnstroff, General Chairman
\end{abstract}

For the next 40 years, with the exception of 1978 the meeting was held annually.

The first 13 conferences were entitled: Application of Optical Instrumentation in Medicine, appended with a roman numeral. The $14^{\text {th }}$ meeting (1986) was modified to recognize the growing importance of PACS to the meeting: Application of Optical Instrumentation in Medicine XIV and Picture Archiving and Communication Systems (PACS IV) for Medical Applications. The following year, the conference name changed to "Medical Imaging" as it is known today, although the first 6 were denoted by roman numerals. Starting in 1993, the year was appended to the title.

The meeting started as a single track, two-day conference, and now has 8 distinct conferences covering five days plus an additional day of courses.

In 1988, the proceedings were published in two volumes, 914A and 914B. The former covering physics, image processing, and perception and the latter display and PACS. The following year (1989) each of those two split in two so that there were now four conferences:

1. Medical Imaging III: Image Formation

2. Medical Imaging III: Image Capture and Display

3. Medical Imaging III: Image Processing

4. Medical Imaging III: PACS System Design and Evaluation

These sessions were partially overlapping and, thus, for the first time, the meeting had parallel session.

This configuration of conferences remained until 1994 when Image Perception and Physiology and Function from Multidimensional Images were added. In 1997, Ultrasonic Transducer Engineering was added. In 2007, ComputerAided Diagnosis was added.

From 1976 to 1983, the meeting was held in conjunction with or preceding the American Roentgen Ray Society. As a result, the location of the meeting changed annually. Starting in 1985, the meeting was held in Newport Beach, CA, and this was home for the next 10 years, except in 1991, the meeting was held in San Jose in conjunction with the Electronic Imaging meeting. In 1995, the meeting was then moved to San Diego, and then returned once more to Newport Beach, before moving to San Diego till 2009. Since 2009 the meeting has been alternating between San Diego and Lake Buena Vista, FL.

In the Introduction to the proceedings in 1984, Chairman Roger Schneider wrote:

This meeting, the twelfth in the series ... was intended to be a change in direction from recent meetings in the series, a reversion to the attack on fundamental problems in imaging which earlier meetings represented. We also desired to bring onto the floor a recognition that the scientific interest in imaging

*r-nishikawa@uchicago.edu|phone: 1-773-702-9047 
is more broad and active now than it was a decade ago and that substantial progress has been made in formulating at least the structure of an understanding of the conveyance of information to human observers through imaging channels. ... We recognized the current intense interest in development of medical systems based upon the most contemporary image communication and storage technologies, and included that topic. The design goal was to address the physics and statistics of image encoding by modality; and the processing, display, archiving, management, and psychophysical considerations independently of modality, as far as possible.

It took 2 years for this new emphasis to flourish. Beginning in 1986, the attendance and the number of papers increased rapidly (as can be seen in the plots below).

Finally, it is important to note that every year for the past 40 years, the Center for Devices and Radiological Health, FDA (formerly, the Bureau for Radiological Health) has been a cosponsor or supporting organization. Further, many members of the CDRH/BRH have helped organize the meeting, such as Robert Wagner, Robert Jennings, Roger Schneider, David Brown and several others. Their contributions to this meeting mirror the impact that the CDRH/BRH have had on the field.
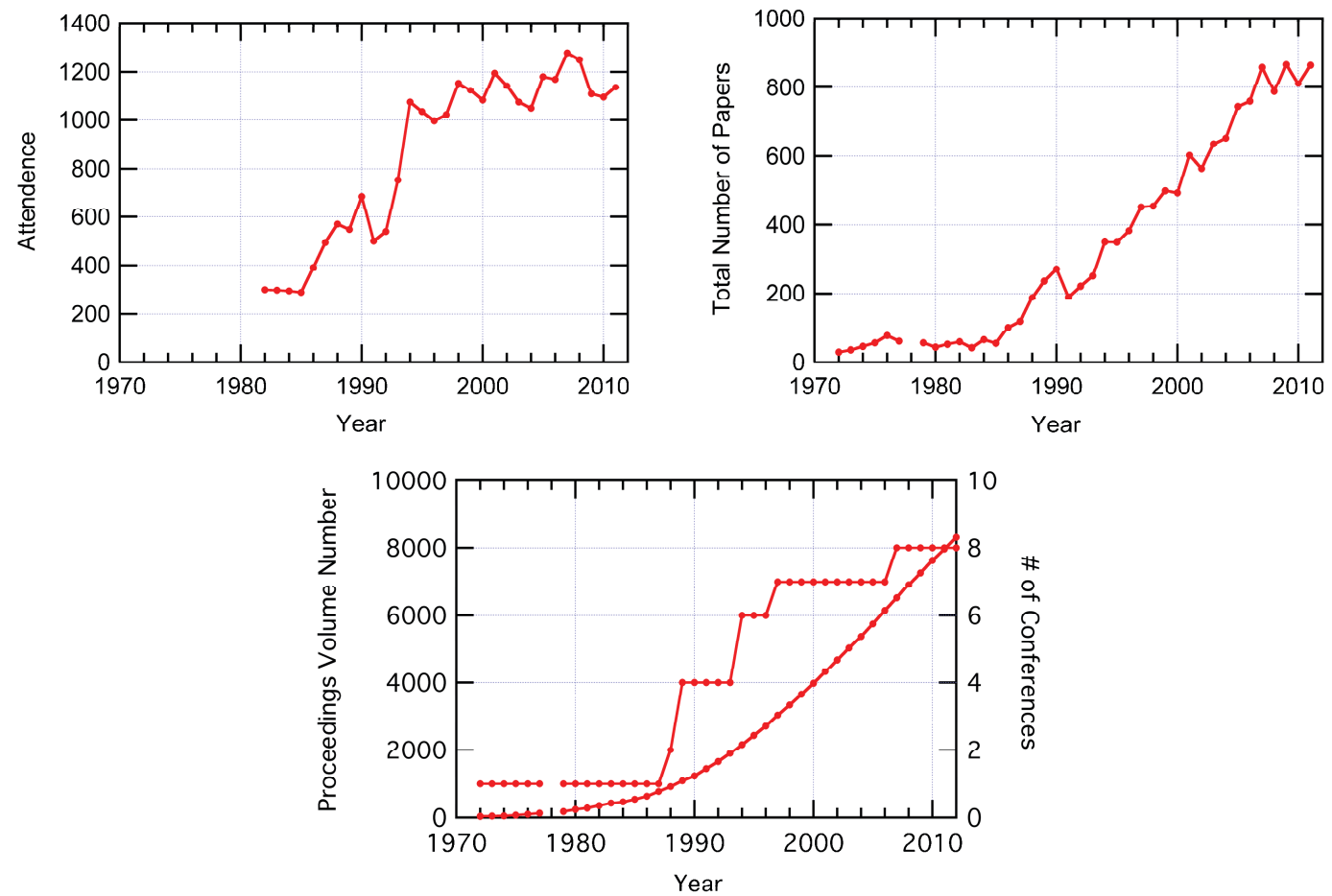

Figure 1. These plots capture some of the statistics from the meeting over time.

\subsection{Fun Facts}

Bob Wagner dubbed 1984-1987, the Palindrome Years.

The first digital mammography paper and the first dual-energy mammography paper were presented in 1983.

The first computer-aided diagnosis (CAD) paper was presented in 1985.

The first Proceedings (Vol. 35) had a black cover and was hard bound. All subsequent Proceedings had a yellow cover and were soft bound.

The first posters were in 1988. Each poster had 3 full poster boards and wine was served at the poster session. 
Although there was no "Medical Imaging" meeting in 1978, there was another medical imaging themed conferences: Recent and Future Developments in Medical Imaging I; edited by Norman A. Baily.

In 2001, the proceedings were distributed on CD for the first time.

Table 1. Number of years serving as a Conference Chair (includes all Conferences) or serving on the Physics Committee (including being Chair). Years on Physics Committee includes committee membership when there was only a single conference and only the Physics Committee when there were multiple conferences.

\begin{tabular}{|l|r|}
\hline \multicolumn{2}{|c|}{ Years Served as a Conference Chair } \\
\hline Samuel J. Dwyer III & 13 \\
\hline Roger H. Schneider & 12 \\
\hline R. Gilbert Jost & 11 \\
\hline Yongmin Kim & 10 \\
\hline William R. Hendee & 8 \\
\hline Anne V. Clough & 7 \\
\hline Murray H. Loew & 7 \\
\hline Joel E. Gray & 6 \\
\hline Kenneth M. Hanson & 6 \\
\hline Steven C. Horii & 6 \\
\hline Arthur G. Haus & 5 \\
\hline Elizabeth A. Krupinski & 5 \\
\hline Eric A. Hoffman & 5 \\
\hline Harold L. Kundel & 5 \\
\hline K. Kirk Shung & 5 \\
\hline Seong K. Mun & 5 \\
\hline William F. Walker & 5 \\
\hline
\end{tabular}

\begin{tabular}{|l|r|}
\hline \multicolumn{2}{|c|}{ Years Served on Physics Committee } \\
\hline Robert F. Wagner & 19 \\
\hline Hans Roehrig & 13 \\
\hline Martin J. Yaffe & 12 \\
\hline Robert J. Jennings & 12 \\
\hline Harrison H. Barrett & 11 \\
\hline Arthur E. Burgess & 10 \\
\hline James T. Dobbins III & 10 \\
\hline John M. Boone & 10 \\
\hline Richard L. Van Metter & 10 \\
\hline Rodney Shaw & 10 \\
\hline Roger H. Schneider & 10 \\
\hline John Yorkston & 9 \\
\hline Kunio Doi & 9 \\
\hline Larry E. Antonuk & 9 \\
\hline Stephen W. Smith & 9 \\
\hline Bruce R. Whiting & 8 \\
\hline Jacob Beutel & 8 \\
\hline Arthur G. Haus & 7 \\
\hline Ian A. Cunningham & 7 \\
\hline John A. Rowlands & 7 \\
\hline Judith M. S. Prewitt & 7 \\
\hline Kenneth M. Hanson & 7 \\
\hline Michael J. Flynn & 7 \\
\hline Murray H. Loew & 7 \\
\hline Robert A. Kruger & 7 \\
\hline Robert M. Nishikawa & 7 \\
\hline Samuel J. Dwyer III & 7 \\
\hline Stephen R. Thomas & 7 \\
\hline Steven C. Horii & 7 \\
\hline Thomas G. Flohr & 7 \\
\hline
\end{tabular}

\subsection{Summary of Each Meeting}

Following is a brief summary of each meeting from 1972-2012. When there were multiple conferences at the meeting, the summary focuses mainly on the Physics Conference. I also have most of this information in an excel spreadsheet. It is available from the author to those who would like it. 


\section{Overview of the 40-Year History of the SPIE Medical Imaging Meeting}

\section{2}

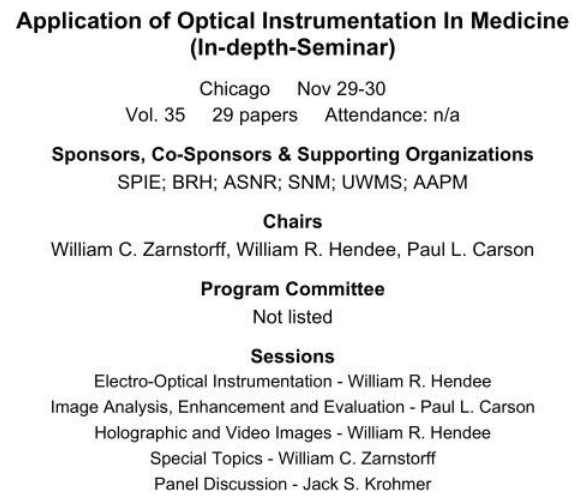

1974

Application of Optical Instrumentation in Medicine III Kansas City, MO Aug 1-2

Vol. 4745 papers Attendance: $n / a$

Sponsors, Co-Sponsors \& Supporting Organizations SPIE; BRH; AAPM, ARRS; EMBG

Chairs

Paul L. Carson, Edward L. Chaney, William R. Hendee

Program Committee

Not listed

Sessions

Transmission 3-Dimensional Image Reconstruction and Computerized Axial Tomography - William R. Hendee, Joseph Gallagher Advanced Techniques of Imaging With Ultrasound - Paul L. Carson Acoustic Exposure Determination In Diagnostic Ultrasound - James A. Rooney

Noise, Objective, and Psychophysical Measures - Joel E. Gray Special Topics - Jacques Ovadia

Ray Tube Focal Spot Size and Intensity Distributions: Important Practica Considerations - Bengt E. Bjarngard

Automatic Brightness Control In Image-Intensified Fluoroscopy - William R. Hendee
1973

Application of Optical Instrumentation in Medicine II

$$
\text { Chicago Nov 29-30 }
$$

Vol. 4335 papers Attendance: $\mathrm{n} / \mathrm{a}$

Sponsors, Co-Sponsors \& Supporting Organizations

SPIE; AAPM; ASNR; AAMI; BRH EMBG; OSA; SNM; SRE; SPSE;

Chairs

William R. Hendee, William C. Zarnstorff, Paul L. Carson

$$
\text { Program Committee }
$$

Not listed

Sessions

Nuclear Medicine Imaging

Image Enhancement and Pattern Recognition

Panel Discussion: Image Enhancement for Medical Diagnosis Can It Be Effective? Special Topics

Image Intensifier Systems

Transmission, Storage, Retrieval and Reconstruction of Images

Panel Discussion Performance Standards and Possible Field Evaluation of Image Intensifiers Performance Standards of Image Intensifiers
1975

Application of Optical Instrumentation in Medicine IV

Atlanta, GA Sept. 25-27

Vol. 7055 papers Attendance: $n / a$

Sponsors, Co-Sponsors \& Supporting Organizations SPIE; BRH; AAPM, ARRS, ACR; SRE

$$
\text { Chairs }
$$

Joel E. Gray, William R. Hendee

Program Committee

Not listed

Sessions

Quality Assurance, Film Handling \& Film Processing - Joel E. Gray Loading, Heat Rating, Other Characteristics of X-Ray Tubes - Edward L. Chaney Information Extraction \& Utilization From Radiologic Images - Marvin E. Haskin Quality Assurance In Diagnostic Radiology: Why Doesn't Every Department Have A
Complete Program? Panel Discussion -

Quality Assurance for Diagnostic Radiologic Instrumentation - James J. Vucich Exposure Initiation/Termination Mechanisms and Automatic Exposure Timers In Diagnostic Radiology - Robert G. Waggener Rare-Earth Intensifying Screens - E. Dale Trout

Panel Discussion: Performance Specifications for Diagnostic Radiologic Equipment -

Gray-Scale Ultrasound Imaging \& Tissue Identification - Paul L. Carson

Physical Evaluation of Computerized Axial Tomography - Raymond P. Rossi Special Topics - Robert Rohrer

Performance Evaluation of Mammographic Imaging Systems - Gregory L. Dubuque 
1976

Application of Optical Instrumentation in Medicine V

Washington, DC Sept. 16-19

Vol. 9676 papers Attendance: $n / a$

Sponsors, Co-Sponsors \& Supporting Organizations SPIE; BRH; ARRS; SRE

Chairs

Robert K. Cacak, Paul L. Carson, Gregory Dubuque, Joel E. Gray, Arthur G. Haus, William R. Hendee, Raymond P. Rossi

Program Committee

Same as Editors

Sessions

Quality Assurance in Diagnostic Radiology 1 - Raymond P. Ross

Quality Assurance in Diagnostic Radiology II - Thomas Stone Computed Tomography I - Norman A. Baily

Radiographic Images and Dose - Arthur G. Haus

Computed Tomography II - Rodney A. Brooks Comput Tom Diagnostic Ultrasound I - Paul L. Carson

Quality Assurance in Diagnostic Radiology III - Robert K. Cacak Current Topics in Mammography - Gregory Dubuque
1977

Application of Optical Instrumentation in Medicine VI

$$
\text { Boston, MA Sept. 25-27 }
$$

Vol. 12760 papers Attendance: $n / a$

Sponsors, Co-Sponsors \& Supporting Organizations SPIE; BRH; ARRS; SRE

$$
\text { Chairs }
$$

Joel E. Gray, William R. Hendee

Program Committee

Robert F. Wagner, William Properzio, Arthur G. Haus, Joie Pierce Jones, Raymond Ross

Sessions

The Laboratory/Clinical Interface in Image Evaluation - Robert Wagner Sensitometry Up-Date - Joel Gray

Screen Film Systems and Photosensitive Materials - Arthur G. Haus Approaches to Equipment Service, Equipment Specification and Performance Evaluation - Raymond P. Rossi

New Developments in Medical Imaging - William Hendee

Quality Control in Medical Imaging - William S. Properzio

Performance Characteristics of CT Scanners - Robert K. Cacak

Small Group Sessions on Special Topics - Joint Session with ARRS

No Meeting

Application of Optical Instrumentation in Medicine VII

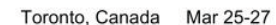

Vol. 17355 papers Attendance: $\mathrm{n} / \mathrm{a}$

Sponsors, Co-Sponsors \& Supporting Organizations

SPIE; SPSE; ARRS; BRH; SRE

$$
\text { Chairs }
$$

Joel E. Gray

Program Committee

Arthur G. Haus, William R. Hendee, Raymond P. Rossi, William Properzio Sessions

Imaging Systems: Physical Evaluation - Joel Gray maging Systems: Perception Evaluation - Joel Gray Imaging Systems: Special Topics - Arthur Haus

Mammography - William Properzio Special Topics - Raymond Rossi

Computed Tomography: Practical Considerations - William R. Hendee Computed Tomography: Theoretical Considerations - William R. Hende X-Ray Imaging Research in Toronto - K. W. Taylor

Joint Session with the ARRS - Joel Gray; William R. Hendee; Harry Z. Mellins 


\section{0}

Application of Optical Instrumentation in Medicine VIII

Las Vegas, NV Apr 20-22

Vol. 23343 papers Attendance: $n / a$

Sponsors, Co-Sponsors \& Supporting Organizations SPIE; SPSE; ARRS; BRH; SRE

\section{Chairs}

Joel Gray, Arthur G. Haus, William R. Hendee, William S. Properzio

Program Committee

Same as Editors

Sessions

Screen-Film Evaluation - Arthur G. Haus Unconventional Imaging Techniques - Joel Gray Special Topics - Gerald Cohen

New Concepts in Conventional Imaging Techniques - James A. Mulvaney How Might Exposure Values Be Determined for Radiological Exams? - William S

Joint Session with the ARRS - Joel Gray; Joseph Calhoun

1982

Application of Optical Instrumentation in Medicine X New Orleans May 9-12

Vol. 34758 papers Attendance: 300

Sponsors, Co-Sponsors \& Supporting Organizations SPIE; ARRS; AAPM; BRH; SPSE; SRE

$$
\text { Chairs }
$$

Gary D. Fullerton, Arthur G. Haus, William S. Properzio, James A. Mulvaney

\section{Program Committee}

Same as Editors

Sessions

Special Session on Digital Radiography - Benjamin A. Arnold; Andrew B. Crummy Conventional Imaging Systems Evaluation - Arthur G. Haus

$$
\text { Digital Radiography - William S. Properzio }
$$$$
\text { Computed Tomography - James A. Mulvaney }
$$

Conventional Imaging Systems Evaluation - Charles A. Kelsey

Break-Out Session A-Digital Radiography - William S. Properzio Break-Out Session B-Conventional Imaging - James A. Mulvaney

Break-Out Session C-Nuclear Magnetic Resonance (NMR) Imaging - Gary D. Fullerton Joint Session with The ARRS - John Tampas; Gary D. Fullerton

Digital Radiology (Cosponsored by The ARRS and SPIE) - M. Paul Capp; William R.

Integrated Systems for Analysis and Display of Radiological Images - Michael J. Flynn Nuclear Magnetic Resonance (NMR) - Raymond L. Nunnally

Nuclear Magnetic Resonance (NMR) (Cosponsored by ARRS and SPIE) - A. Everette James; Raymond L. Nunnally
(NMR) (Cosponsored by ARRS

\section{1}

Application of Optical Instrumentation in Medicine IX San Francisco, CA Mar 22-24

Vol. 27351 papers Attendance: $n / a$

Sponsors, Co-Sponsors \& Supporting Organizations SPIE; SPSE; AAPM; ARRS; BRH; SRE

\section{Chairs}

Joel E. Gray, Arthur G. Haus, William S. Properzio, James A. Mulvaney

\section{Program Committee}

Same as Editors

Sessions

Special Session: Nuclear Magnetic A. Everette James. Jr.

Conventional Imaging Systems Evaluation - Arthur G. Haus

Digital Radiography - William S. Properzio

Quality Control - James A. Mulvaney

Nuclear Medicine - Joel E. Gray

Break-Out Session A: Nuclear Magnetic Resonance - C. Leon Partain

Break-Out Session B: Computerized Tomography - Gary D. Fullerton Break-Out Session C: Digital Imaging - William S. Properzio

Break-Out Session D: Conventional Imaging Systems Evaluation - Joel E. Gray

Joint Session with the ARRS - Arthur G. Haus; James F. Martin

Computerized Tomography - Gary D. Fullerton

Recording, Storage, and Processing of Images - Joel E. Gray

\section{3}

Application of Optical Instrumentation in Medicine XI

$$
\text { Atlanta Apr 17-20 }
$$

Vol. 41941 papers Attendance: 298

Sponsors, Co-Sponsors \& Supporting Organizations SPIE; ARRS; AAPM; BRH SPSE; SRE

Chairs

Gary D. Fullerton

Program Committee

Arthur G. Haus, James A. Mulvaney, William Properzio

Sessions

Advances in Breast Imaging - Roger S. Powell

Conventional Imaging Systems Evaluation - Arthur G. Haus Digital Radiography I - James A. Mulvaney

Image Performance Evaluation and Quality Assurance - William S. Properzio Digital Radiography II - Stewart C. Bushong

Breakout Session A-Nuclear Magnetic Resonance Imaging - Gary D. Fullerton

Breakout Session B-Digital Radiography - William S. Properzio

Breakout Session C-Conventional Imaging - James A. Mulvaney

Joint Session with SPIE and The ARRS - Melvin M. Figley; Gary D. Fullerton

Nuclear Magnetic Resonance Imaging - Gary D. Fullerton

New Modalities and Computers in Medical Imaging - Michael J. Flynn 


\section{4}

Application of Optical Instrumentation in Medicine XII

San Diego, CA Feb 26-29

Vol. 45464 papers Attendance: 295

Sponsors, Co-Sponsors \& Supporting Organizations

SPIE; EFOMP; JPL; CDRH; SRE

Chairs

Samuel J. Dwyer III, Roger H. Schneider

Program Committee

David G Brown; Arthur Burgess; Kunio Doi; Andre J Duerinckx; Melvin Figley; Kenneth M. Hanson; Steven C Horii; Robert J. Jennings; Leon Kaufman;

Vincent J Sodd; Michel M Ter-Pogossian; Robert F Wagner

\section{Sessions}

The Physics and Statistics of Imaging I - Kenneth M. Hanson

The Physics and Statistics of Imaging II - Arthur Burgess

Non-ionizing imaging modalities - Robert J. Jenning

Management of Image Data - Judith M. S. Prewitt

Performance Analysis of X-Ray Screen-Film Systems - Robert F. Wagner

Data Processing for Image Formation, Enhancement, \& Mensuration I - James L. Lehr Image Display Systems I - Steven C. Horii

Data Processing for Image Formation, Enhancement, \& Mensuration II - Kunio Do Data Processing for Image Formation, Enhancement, \& Mensuration II - Murray Loew Image Display Systems II - Samuel J. Dwyer III Photoeletronic imaging devices - Hans Roehrig

Data Processing for Image Formation, Enhancement, and Mensuration III - Melvin M. Figley

Computerized Tomography and Nuclear Medicine - Roger H. Schneider

\section{6}

Application of Optical Instrumentation in Medicine XIV and Picture Archiving and Communication Systems

Newport Beach, CA Feb 2-7

Vol. 626101 papers Attendance: 391

Sponsors, Co-Sponsors \& Supporting Organizations SPIE; AAPM; CDRH

Chairs

Samuel J. Dwyer III, Roger H. Schneider

Program Committee

Laurens V Ackerman; Ronald I Arenson; Harrison H Barrett; Roger A Bauman David G. Brown; Stuart I. Brown; Arthur E Burgess; Arthur Carson; Kunio Doi; James F. Dunn; Kenneth M. Hanson; Shankar S. Hegde; David G. Hill; Steven C. Horii; H. K. Huang; Robert J. Jennings; Bruce Laskin; Robert A. Kruger; James L Lehr; Thomas K. Lewellen; Murray H. Loew; Albert Macovski; William C. Mortimore; Judith M. S. Prewitt; Roland W.Redington; Stephen Riederer; Rodney Shaw; Stephen W. Smith, Edward Staab; Stephen R. Thomas; Henry N.Wagner Jr.; Robert F. Wagner; Jason S. Zielonka

\section{Sessions}

New Signals in Medical Imaging I \& II - Roger H. Schneider \& Stephen J. Riederer mage Formation I - IV - Kunio Doi; Robert J. Jennings; H. K. Huang; Stephen R. Thoma: Image Perceptions - Robert F. Wagner

Image Processing I - III - Murray H. Loew; Robert A. Kruger; Arthur E. Burgess Digital Image Capture and Formatting I \& II - David R. Pickens \& Thomas K. Lewellen Digital Image Display I- III - James L. Lehr; Steven C. Horii; Stephen M. Pizer PACS System Design and Evaluation I - V - Ronald L. Arenson; Edgar Alzner; R. Gilbert Jost; Roger A. Bauman; B. G. Thompson Archives for PACS - Judith M. S. Prewitt Operations Analysis and Modeling of Radiology Departments I \& II - Shakar S. Hegde \&
Samuel J. Dwyer III
1985

Application of Optical Instrumentation in Medicine XIII Newport Beach, CA Feb 3-6

Vol. 53554 papers Attendance: 289

Sponsors, Co-Sponsors \& Supporting Organizations

SPIE; CDRH; SRE; IEEE-CS

Chairs

Samuel J. Dwyer III, Roger H. Schneider

Program Committee

Roger Bauman; Stuart I Brown; Arthur Burgess; Kunio Doi; Andre J Duerinckx: Melvin M. Figley; Kenneth M. Hanson; Steven C. Horii; H. K. Huang; Robert J. Jennings; James L. Lehr; Murrey Loew; Albert Macovski; Judith M. S. Prewitt; Rodney Shaw; Stephen W Smith; Michel M Ter-Pogossian; Robert F Wagner

Sessions

Image Statistics \& Perception: I- Kunio Do Image Statistics \& Perception: II - Robert F. Wagner Image Statistics \& Perception: III - Arthur Burgess Computing Images From Data - Kenneth M. Hanson Detector Physics I: Scatter - H. K. Huang

Detector Physics II: Film Screen Systems - Rodney Shaw; Robert J. Jennings Detector Physics III: Digital - Albert Macovski

Detector Physics IV: Semiconductors \& Photoconductors - Roger Schneider Detector Physics V: Ultrasound \& NMR - Stephen W. Smith Photography. Stuart I. Brown - University Hospital Image Processing I: General - James L. Lehr Image Processing II A: Task Oriented Cranial - Murray Loew Image Processing || B: Task Oriented-Chest - Gordon Image Processing II C: Task Oriented-Gastro Intestinal - Steven C. Horii

\section{7}

Medical Imaging

Newport Beach, CA Feb 1-6

Vol. 767 (two volumes) 119 papers Attendance: 494

Sponsors, Co-Sponsors \& Supporting Organizations SPIE; AAPM; CDRH Chairs

Samuel J. Dwyer III, Roger H. Schneider Program Committee

Laurens V. Ackerman; Ronald L. Arenson; Harrison H. Barrett; Roger A. Bauman; Arthur E. Burgess; Arthur Carson; Kunio Doi; Leonard A. Ferrari; Kenneth M. Hanson; Shankar S. Hegde; William R. Hendee; David G. Hill;
Steven Horii; H.K. Huang; Robert Jennings; Robert Kruger; Bruce Laskin; Steven Horii; H.K. Huang; Robert Jennings; Robert Kruger; Bruce Laskin;
ames L. Lehr; Thomas Lewellyn; Murray Lowe; William Mortimore; Lara Le Murphy; Stephen M. Pizer; Judith M. S. Prewitt; Ronald R. Price; Stephen J. Riederer; Hans Roehrig; Rodney Shaw; Stephen W. Smith; Edward Staab; Stephen R Thomas; Henry N Wagner Jr; Robert F Wagner; Jason S Zielonk

\section{Sessions}

Future Potential of Several Candidate Signals for Medical Imaging | \& || - Roger $\mathrm{H}$. Schneider / Stephen R. Thomas

Tomographic Reconstruction - Harrison H. Barrett

Radiography I \& II - Robert J. Jennings / Hans Roehrig Fluoro/Angio - Ronald R. Price

Imaging Performance Measures - Kunio Doi

Image Formatting and Compression - H. K. Huang Perception - Arthur E. Burgess

Sephen J. Riederer / Rodney Shaw / David G. Hill / Robert A. Kruger / Yongmin Kim / Edward Staab

Printers, Displays, and Digitizers - Roger A. Bauman

PACS at the UCLA /PACS at Univ of Arizona - H. K. Huang / William J. Dallas 3-D Display - James L. Lehr

Workstations and the Display - Observer Interface I \& II- Stephen Pizer / Steven C. Horii Networking Issues - Chris Stockbridge

PACS I - III - Laura Lee Murphy / Samuel J. Dwyer III / Steven C. Horii 
1988

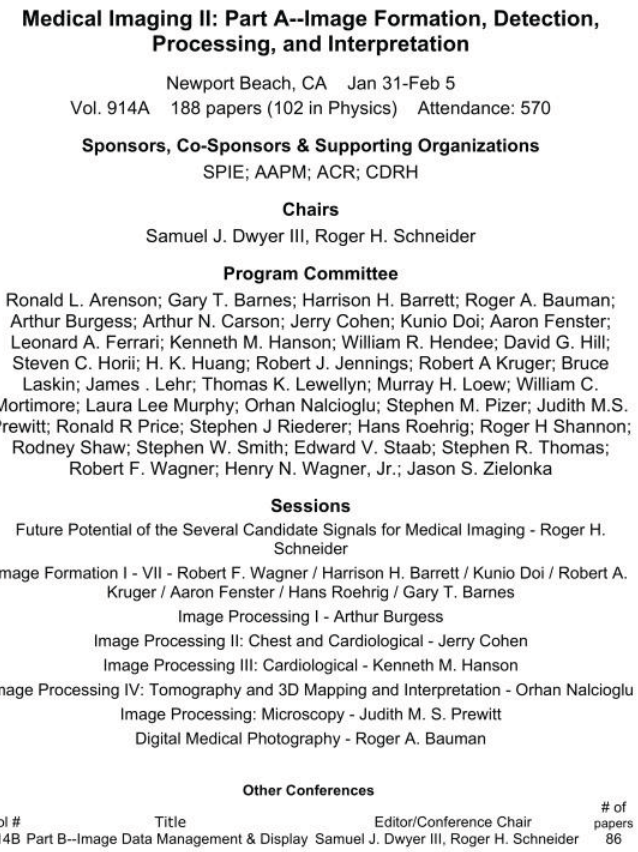

1990

Medical Imaging IV: Image Formation

Newport Beach, CA Feb 4-6

Vol. 1231270 papers (60 in Physics) Attendance: 686

Sponsors, Co-Sponsors \& Supporting Organizations SPIE; AAPM; ACR;CDRH; NEMA

Chairs

Roger H. Schneider

Program Committee

Ronald L. Arenson; Harrison H. Barrett; Roger A. Bauman; David G. Brown; Arthur E. Burgess; Gerald Cohen; William Dallas; Kunio Doi; Samuel J. Dwyer II Aaron Fenster; Kenneth M. Hanson; David G. Hill; Robert Hindel; Steven C. Horii; H. K. Huang; Robert J. Jennings; R. Gilbert Jost; Yongmin Kim; Robert A. Kruger; Pei-Jan Paul Lin; Murray H. Loew; Richard L. Morin; Seong Ki Mun; Jhan Nalcioglu, Thomas R. Nelson, David R. Pickens, Stephen M. Pizer, Judit Stephen W. Smith; Edward V. Staab; Stephen R. Thomas; Robert F. Wagner

$$
\text { Sessions }
$$

Future Potential of Bioeletromagnetic and Ultrasound Imaging - Roger $\mathrm{H}$. Schneider Future Potential of Ultrasound, CT, and Optical Imaging - Stephen W. Smith Future Potential of Optical Imaging - William J. Dallas MRI - Stephen R. Thomas

Calculated Images - Rodney Shaw CT - Orhan Nalcioglu

Film Screen Systems - Kunio Doi Digital Quantum Imagers I - Hans Roehrig Digital Quantum Imagers II - Aaron Fenster Clinical Systems and Issues - Robert J. Jennings

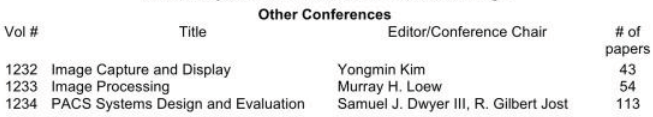

1989

Medical Imaging III: Image Formation

Newport Beach, CA Jan 29-31

Vol. 1090235 papers (51 in Physics) Attendance: 547

Sponsors, Co-Sponsors \& Supporting Organizations SPIE; AAPM; ACR: CDRH; IRS

Chairs

Samuel J. Dwyer III, R. Gilbert Jost M.D., Roger H. Schneider

Program Committee

Ronald L. Arenson; Harrison H. Barrett; Gary T. Barnes; Roger A. Bauman; David G. Brown; Arthur E. Burgess; Arthur Carson; Gerald Cohen; Kunio Do Aaron Fenster; Kenneth M. Hanson; William R. Hendee; David G. Hill; Steven C. Horii; H K. Huang; Robert J. Jennings; Robert A. Kruger; James L. Lehr; Thomas K. Lewellen; Murray R. Loew; Orhan Nalcloglu; Stephen M. Pizer; Judith M. S. Prewitt; Ronald Price; Stephen J. Riederer;

Hans Roehrig; Roger H. Shannon; Rodney Shaw; Stephen W. Smith;

Edward Staab; Stephen R. Thomas; Robert F. Wagner Sessions
Future Potential of the Several Candidate Signals for Medical Imaging - Roger $\mathrm{H}$.
Schneider

Image Formation I - Stephen J. Riederer Image Formation II - Robert J. Jennings Image Formation III - Arthur E. Burgess Image Formation IV - Robert A. Kruger Image Formation $\mathrm{V}$ - Kunio Doi Image Formation VI - Ronald R. Price

\begin{tabular}{|c|c|c|}
\hline \multicolumn{2}{|c|}{ Other Confe } & \\
\hline Vol \# & Editor/Conference Chair & papers \\
\hline 1091 Image Capture and Display & $\begin{array}{l}\text { Samuel J. Dwyer III, R. Gilbert Jost, } \\
\text { Roger H. Schneider }\end{array}$ & 44 \\
\hline 1092 Image Processing & $\begin{array}{l}\text { Samuel J. Dwyer III, R. Gilbert Jost, } \\
\text { Roger H. Schneider }\end{array}$ & 71 \\
\hline 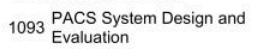 & $\begin{array}{l}\text { Samuel J. Dwyer III, R. Gilbert Jost, } \\
\text { Roger H. Schneider }\end{array}$ & 69 \\
\hline
\end{tabular}

1991

Medical Imaging V: Image Physics

San Jose, CA Feb 25-26

Vol. 1443190 papers (26 in Physics) Attendance: 500

Sponsors, Co-Sponsors \& Supporting Organizations SPIE; AAPM; ACR;CDRH; IS\&TNEMA

Chairs

Roger H. Schneider

Program Committee

Harrison H. Barrett; David G. Brown; Arthur E. Burgess; William J. Dallas; Kunio

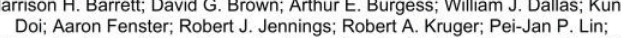
Doi; Aaron Fenster; Robert J. Jennings; Robert A. Kruger; Pei-Jan P. Lin; Smith; Stephen R. Thomas; Robert F. Wagner

Sessions

Magnetic Imaging - Roger H. Schneider Acoustic Imaging - David G. Brown

Radiographic and Fluoroscopic Detectors and Systems - Hans Roehrig Decision Makers and Displays - Arthur E. Burgess Computing Images: $\mathrm{CR}, \mathrm{CT}$, and PET - Kenneth M. Hanson Cone Beam CT - Aaron Fenster Optical Imaging - Aaron Fenster

Vol \# Title Editor/Conference Chair \# of

1444 Image Capture, Formatting, and Yongmin Kim $\quad 48$ Display

Murray H. Loew

1446 PACS Design and Evaluation

R. Gilbert Jost 
Medical Imaging VI: Instrumentation

Newport Beach, CA 23-24 February

Vol. 1651221 papers (27 in Physics) Attendance: 539

Sponsors, Co-Sponsors \& Supporting Organizations SPIE; AAPM; CDRH; NEMA; IS\&T

Chairs

Rodney Shaw

Program Committee

Harrison H. Barrett; David G. Brown; Arthur E. Burgess; William J. Dallas; Kunio Doi; Aaron Fenster; Robert J. Jennings; Robert A. Kruger; Pei-Jan Paul Lin; Richard L. Morin; Orhan Nalcioglu; Hans Roehrig; Roger H. Schneider;

Stephen W. Smith; Stephen R. Thomas; Robert F. Wagner

\section{Sessions}

Image Instrumentation I - David G. Brown

mage Instrumentation II - Arthur E. Burgess

Image Instrumentation III - William J Dalla

Image Instrumentation IV - Hans Roehrig

Poster Session

\begin{tabular}{|c|c|c|}
\hline \multirow{2}{*}{\multicolumn{3}{|c|}{ Other Conferences }} \\
\hline & & \\
\hline $\begin{array}{l}165 \\
165\end{array}$ & $\begin{array}{l}\text { Image Processing } \\
\text { Image Capture, Formatting, and } \\
\text { Display }\end{array}$ & $\begin{array}{l}\text { Murray H. Loew } \\
\text { Yongmin Kim }\end{array}$ \\
\hline
\end{tabular}

1994

Medical Imaging 1994: Physics of Medical Imaging

Newport Beach, CA 13-14 February

Vol. 2163349 papers (45 in Physics) Attendance: 1073

Sponsors, Co-Sponsors \& Supporting Organizations

SPIE; AAPM; BOS; CDRH; NEMA;IS\&T; RISC; RSNA; SCAR

Chairs

Rodney Shaw

Program Committee

Jacob Beutel; John M. Boone; Randall P. Brown; Robert J. Jennings: Hans Roehrig; Richard L. Van Metter; Robert F. Wagner; Martin J. Yaffe

Sessions

Physics of Medical Imaging I - Hans Roehrig

Physics of Medical Imaging II - Martin J. Yaffe

Physics of Medical Imaging III - Randall P. Brown

Physics of Medical Imaging IV - Robert J. Jennings

Physics of Medical Imaging V - John M. Boon

Physics of Medical Imaging VI - Jacob Beutel

Physics of Medical Imaging VII - Richard L. Van Metter

Vol \#- Other Conferences

2164 Image Capture, Formatting, and Yongmin Kim Display

2165 PACS: Design and Evaluation

2166 Image Perception

Multidimensional Images
Medical Imaging 1993: Physics of Medical Imaging

Newport Beach, CA 14-15 February

Vol. 1896250 papers ( 45 in Physics) Attendance: 754

Sponsors, Co-Sponsors \& Supporting Organizations

SPIE; AAPM; BOS; CDRH; NEMA:IS\&T; SCAR

Rodney Shaw

Program Committee

Jacob Beutel; Arthur E Burgess; Robert J. Jennings; Hans Roehrig; Richard L. Van Metter; Robert F. Wagner

Sessions

Physics of Medical Imaging I - Robert F. Wagner Physics of Medical Imaging II - Rodney Shaw Physics of Medical Imaging III - Hans Roehrig Physics of Medical Imaging IV - Robert F. Wagner Physics of Medical Imaging $V$ - Robert J. Jennings Physics of Medical Imaging VI - Jacob Beutel Physics of Medical Imaging VI - Jacob Beutel
Physics of Medical Imaging VII - Richard L. Van Metter

\begin{tabular}{|c|c|c|c|}
\hline \multicolumn{4}{|c|}{ Other Conferences } \\
\hline Vol \# & Title & Editor/Conference Chair & $\begin{array}{c}\text { \# of } \\
\text { papers }\end{array}$ \\
\hline & $\begin{array}{l}\text { Image Capture, Formatting, and } \\
\text { Display }\end{array}$ & Yongmin Kim & 51 \\
\hline 189 & Image Processing & Murray H. Loew & 86 \\
\hline & PACS Design and Evaluation & R. Gilbert Jost & 68 \\
\hline
\end{tabular}

1995

Medical Imaging 1995: Physics of Medical Imaging

San Diego, CA 26-27 February

Vol. 2432348 papers (60 in Physics) Attendance: 1034

Sponsors, Co-Sponsors \& Supporting Organizations

SPIE; AAPM; APS CDRH; IS\&T; NEMA; RISC; RSNA; SCAR

Chairs

Richard L. Van Metter, Jacob Beute

Program Committee

Larry E. Antonuk; Gary T. Barnes; John M. Boone; Randall P. Brown; Ian A. Cunningham; Frank A DiBianca; James T Dobbins III; Robert J Endorf; Robert Jennings; Hans Roehrig; Robert F Wagner; Martin J Yaffe; Herbert D Zeman

$$
\text { Sessions }
$$

Image Quality and X-Ray Physics I - John M. Boone Image Quality and X-Ray Physics II - Robert J. Jennings

Image Quality and X-Ray Physics III - Hans Roehrig

Physics of Ultrasound Imaging - Randall P. Brown

Novel Detectors for Digital Radiography I - Martin J. Yaffe Novel Detectors for Digital Radiography II - Frank A. DiBianca Novel Detectors for Digital Radiography III - lan A. Cunningham Digital Radiography System Performance - Larry E. Antonuk

\begin{tabular}{|c|c|c|c|}
\hline & \\
\hline & Title & Editor/Conference Chair & $\begin{array}{l}\text { \# of } \\
\text { papers }\end{array}$ \\
\hline 31 & Image & Yongmin & \\
\hline & $\begin{array}{l}\text { Physiology and Function from } \\
\text { Multidimensional Images }\end{array}$ & Eric $A$ & 47 \\
\hline 4 & Image & & \\
\hline & $\begin{array}{l}\text { PACS Design and Evaluation: } \\
\text { Engineering and Clinical Issues }\end{array}$ & $\begin{array}{l}\text { R. Gilbert Jost, Samuel J. } \\
\text { Dwyer III }\end{array}$ & 67 \\
\hline & get & tarold L. Kundel & 15 \\
\hline
\end{tabular}


1996

\section{Medical Imaging 1996: Physics of Medical Imaging}

Newport Beach, CA 11-13 February

Vol. 2708382 papers (79 in Physics) Attendance: 996

Sponsors, Co-Sponsors \& Supporting Organizations

Chairs

Richard L. Van Metter, Jacob Beutel

Program Committee

Larry E. Antonuk; Gary T. Barnes; John M. Boone; Randall P. Brown; lan A. Cunningham; Frank A. DiBianca; James T. Dobbins III; Robert J. Endorf; Hans Roehrig; Robert F. Wagner; Martin J. Yaffe; Herbert D. Zeman

\section{Sessions}

Plenary Session - Robert Wagne

New Concepts in Information Theory - Hans Roehrig Image Quality and X-Ray Physics I - John M. Boone Image Quality and X-Ray Physics II - John M. Boone Image Quality and X-Ray Physics III - Robert J. Endor

Mammographic Imaging - Martin J. Yaffe Ultrasound - Herbert D. Zeman

Volume Imaging I - Frank A. DiBianca

Volume Imaging II - Frank A. DiBianca

Detectors for Digital Radiography I - Larry E. Antonuk

Detectors for Digital Radiography II - James T. Dobbins II

Vol \#

Other Conferences

2707 Image Display Title Yongmin Kim

2709 Physiology and Function from Eric A. Hoffman

2710 Image Processing

2711 PACS Design and Evaluation: Engineering and Clinical Issues

2712 Image Perception

Murray Loew, Kenneth Hanson 102

R. Gilbert Jost, Samuel J. 66

Dwyer III

Harold L. Kundel
SPIE; AAPM; APS; CDRH; IS\&T; NEMA; RISC; RSNA; SCAR

1997

\section{Medical Imaging 1997: Physics of Medical Imaging}

San Jose, CA Feb 23-25

Vol. 3032451 papers ( 57 in Physics) Attendance: 1021

Sponsors, Co-Sponsors \& Supporting Organizations

SPIE; AAPM; APS; CDRH; IS\&T; NEMA; RISC; RSNA; SCAR

Chairs

Richard L. Van Metter, Jacob Beutel

Program Committee

Larry E. Antonuk; Gary T. Barnes; John M. Boone; Ian A. Cunningham; Frank A. DiBianca; James T. Dobbins III: Robert J Endorf; Gary S. Keyes; Hans Roehrig; Robert F. Wagner; Martin J. Yaffe; Herbert D. Zeman

\section{Sessions}

Image Acquisition I - John M. Boone

Image Acquisition II - Frank A. DiBianc

Imaging Physics I - Robert F. Wagner

Imaging Physics II - Hans Roehrig

Volume Imaging I - Herbert D. Zeman

Volume Imaging II - Robert J. Endorf

Mammographic Imaging - Martin J. Yaffe

Film/Screen and CR Imaging - lan A. Cunningham

\begin{tabular}{|c|c|c|c|}
\hline \multicolumn{4}{|c|}{ Other Conferences } \\
\hline Vol \# & Title & Editor/Conference Chair & $\begin{array}{l}\text { \# of } \\
\text { paner }\end{array}$ \\
\hline 3031 & Image Display & Yongmin Kim & 87 \\
\hline 3033 & $\begin{array}{l}\text { Physiology and Function from } \\
\text { Multidimensional Images }\end{array}$ & Eric A. Hoffman & 46 \\
\hline 3034 & Image Processing & Kenneth M. Hanson & 123 \\
\hline 3035 & $\begin{array}{l}\text { PACS Design and Evaluation: } \\
\text { Engineering and Clinical Issues }\end{array}$ & $\begin{array}{l}\text { Steven C. Horii, G. James } \\
\text { Blaine }\end{array}$ & 78 \\
\hline 3036 & Image Perception & Harold L. Kundel & 35 \\
\hline 3037 & $\begin{array}{l}\text { Ultrasonic Transducer } \\
\text { Engineering }\end{array}$ & K. Kirk Shung & 25 \\
\hline
\end{tabular}

\section{8}

\section{9}

Medical Imaging 1998: Physics of Medical Imaging

San Diego, CA Feb 22-24

Vol. 3336454 papers ( 86 in Physics) Attendance: 1153

Sponsors, Co-Sponsors \& Supporting Organizations

SPIE; AAPM; APS; CDRH; IS\&T; NEMA RISC; RSNA; SCAR

Chairs

James T. Dobbins III, John M. Boone

\section{Program Committee}

Larry E. Antonuk; Gary T. Barnes; Jacob Beutel; Ian A. Cunningham; Frank A DiBianca; Robert J. Endorf; Gary S. Keyes; Hans Roehrig; Robert F. Wagner; Martin J. Yaffe; Richard L. Van Metter; Herbert D. Zeman

\section{Sessions}

X-Ray Detectors I - Richard L. Van Mette X-Ray Physics - Gary S. Keyes Non-lonizing Imaging - Robert J. Endorf X-Ray Detectors II - Martin J. Yaffe Mammographic Imaging - John M. Boone Imaging Theory - Robert F. Wagner Volume Imaging - lan A. Cunningham Imaging Physics - Hans Roehrig

Real-Time X-Ray Detectors - Frank A. DiBianc

X-Ray Detectors III - James T. Dobbins III

\begin{tabular}{|c|c|c|c|}
\hline \multirow[b]{2}{*}{ Vol \# } & \multicolumn{3}{|c|}{ Other Conferences } \\
\hline & Title & Editor/Conference Chair & $\begin{array}{l}\text { \# of } \\
\text { papers }\end{array}$ \\
\hline 3335 & Image Display & Yongmin Kim, Seong K. Mun & 70 \\
\hline 3337 & $\begin{array}{l}\text { Physiology and Function from } \\
\text { Multidimensional Images }\end{array}$ & Eric A. Hoffman & 39 \\
\hline 3338 & Image Processing & Kenneth M. Hanson & 15 \\
\hline 3339 & $\begin{array}{l}\text { PACS Design and Evaluation: } \\
\text { Engineering and Clinical Issues }\end{array}$ & $\begin{array}{l}\text { Steven C. Horii, G. James } \\
\text { Blaine }\end{array}$ & \\
\hline 3340 & Image Perception & Harold L. Kundel & \\
\hline 3341 & Ultrasonic Transducer Engine & K. Kirk Shung & \\
\hline
\end{tabular}

Medical Imaging 1999: Physics of Medical Imaging

San Diego, CA Feb 21-23

Vol. 3659 (in 2 vol) 499 papers (99 in Physics) Attendance: 1123

Sponsors, Co-Sponsors \& Supporting Organizations SPIE; AAPM; APS; CDRH; IS\&T; NEMA; RSNA; SCAR

Chairs

John M. Boone, James T. Dobbins III

\section{Program Committee}

Larry E. Antonuk; Jacob Beutel; Ian A. Cunningham; Frank A. DiBianca; Robert J. Endorf; Gary S. Keyes; Hans Roehrig; Robert F. Wagner; Martin J. Yaffe; Richard L. Van Metter; Herbert D. Zeman

Direct X-Ray Detectors - Richard L. Van Metter Imaging Theory - Robert F. Wagner Mammography I - Martin J. Yaffe

Computer Tomography - Gary S. Keyes Ultrasound - Ian A. Cunningham Imaging Physics - Frank A. DiBianca Indirect X-Ray Detectors I - Larry E. Antonuk New Frontiers - Hans Roehrig

Mammography II - Jacob Beutel Thoracic Imaging - John M. Boone Indirect X-Ray Detectors II - James T. Dobbins II

\begin{tabular}{|c|c|c|c|}
\hline \multicolumn{4}{|c|}{ пе } \\
\hline $\begin{array}{l}\text { Vol \# } \\
3658\end{array}$ & Image Display & $\begin{array}{l}\text { Editor/Conference Chair } \\
\text { Seong K. Mun, Yongmin Kim }\end{array}$ & $\begin{array}{l}\text { papers } \\
60\end{array}$ \\
\hline 3660 & $\begin{array}{l}\text { Physiology and Function from } \\
\text { Multidimensional Images }\end{array}$ & Chin-Tu Chen, Anne V. Clough & 1 \\
\hline & Image Processing & Kenneth M. Hansc & 170 \\
\hline & $\begin{array}{l}\text { PACS Design and Evaluation: } \\
\text { Engineering and Clinical Issues }\end{array}$ & G. James Blaine, Steven C. Horii & 52 \\
\hline & Image Perception and Performance & Elizabeth A. Krupinski & 39 \\
\hline & Itrasonic Transducer Engineeri & K. Kirk Shun & 28 \\
\hline
\end{tabular}

$$
\text { Sessions }
$$


2000

Medical Imaging 2000: Physics of Medical Imaging

San Diego, CA Feb 13-15

Vol. 3977493 papers (71 in Physics) Attendance: 1082

Sponsors, Co-Sponsors \& Supporting Organizations

SPIE; AAPM; APS; CDRH; EMBS; IS\&T; NEMA; RSNA; SCAR

\section{Chairs}

James T. Dobbins III, John M. Boone

Program Committee

Larry E. Antonuk; Jacob Beutel; lan A. Cunningham; Frank A. DiBianca; Gary S. Keyes; Andrew D. A. Maidment; Robert A. Street; Robert F. Wagner; Martin J. Yaffe

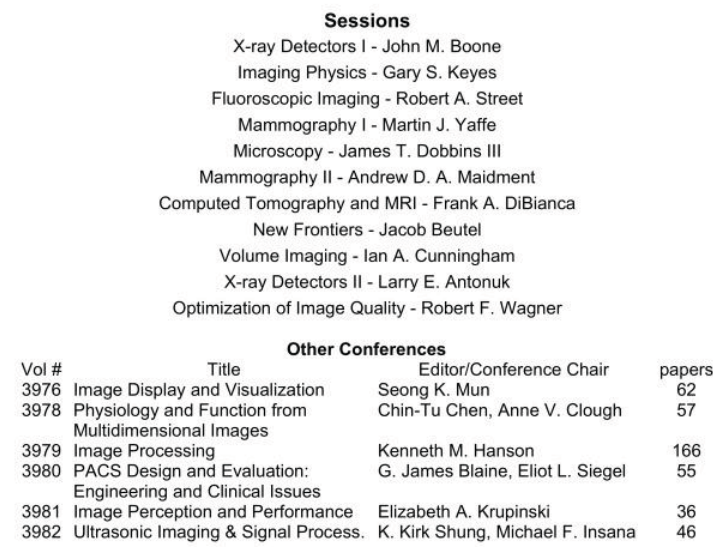

2002

Medical Imaging 2002: Physics of Medical Imaging

San Diego, CA 23 - 28 February

Vol. 4682564 papers (90 in Physics) Attendance: 1142

Sponsors, Co-Sponsors \& Supporting Organizations

SPIE; AAPM; APS; CDRH; IS\&T; NEMA; RSNA; SCAR

Chairs

Larry E. Antonuk, Martin J. Yaffe

Program Committee

Katherine P. Andriole; John M. Boone; Tom J. Bruijns; Michael J. Flynn; Paul R. Granfors; Andrew D. Maidment; Robert A. Street; John Yorkston; Wei Zhao

Sessions

X-Ray Detectors I - Imaging Physics

Volume Imaging I - Breast Imaging

Volume Imaging II - Novel Imaging Methods I

Fluoroscopy/Real Time - Volume Imaging III

X-Ray Detectors II - X-Ray Detectors III//maging Physics II

Novel Imaging Methods II - Poster Session

\begin{tabular}{|c|c|c|c|}
\hline \multicolumn{4}{|c|}{ Other Conferences } \\
\hline Vol\# & Title & Editor/Conference Chair & \\
\hline 4681 & $\begin{array}{l}\text { Visualization, Image-Guided } \\
\text { Procedures, and Display }\end{array}$ & Seong K. Mun & \\
\hline 4683 & $\begin{array}{l}\text { and Function from } \\
\text { sional Images }\end{array}$ & Anne V. Clough, Chin-Tu Chen & 53 \\
\hline 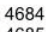 & Image & & \\
\hline 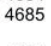 & $\begin{array}{l}\text { PACS and Integrated Medical } \\
\text { Information Sys: Design \& Evaluation }\end{array}$ & & \\
\hline 4686 & $\begin{array}{l}\text { Image Perception, Observer } \\
\text { Performance, and Technology } \\
\text { Assessment }\end{array}$ & $\begin{array}{l}\text { Dev P. Chakraborty, Elizabeth A. } \\
\text { Krupinski }\end{array}$ & 40 \\
\hline 68 & $\begin{array}{l}\text { Ultrasonic Imaging and Signal } \\
\text { Processing }\end{array}$ & $\begin{array}{l}\text { Michael F. Insana, William F. } \\
\text { Walker }\end{array}$ & 4 \\
\hline
\end{tabular}

2001

Medical Imaging 2001: Physics of Medical Imaging

San Diego, CA Feb 17-23

Vol. 4320602 papers (103 in Physics) Attendance: 1195

Sponsors, Co-Sponsors \& Supporting Organizations

SPIE; AAPM; APS; CDRH; IS\&T; NEMA; RSNA; SCAR

Chairs

Larry E. Antonuk, Martin J. Yaffe

Program Committee

Katherine P. Andriole; Tom J. Bruijns; lan A. Cunningham; Kathes T. P. Andrill; Tomal. Bryilns; Andrew D. Maidmer Robert A. Street; Robert F. Wagner; John Yorkston

Sessions

X-ray Detectors I - Larry E. Antonuk Imaging Physics I - Ian A. Cunningham Fluoroscopic Imaging - Katherine P. Andriole Mammography I-Andrew D. Maidment X-ray Detectors II - Robert A. Street CT/MRI - Michael J. Flynn

Novel Imaging Methods I - James T. Dobbins II Imaging Physics II/Keynote - Martin J. Yaffe Volume Imaging - Tom J. Bruijns Novel Imaging Methods II - John Yorkston X-ray Detectors III - Robert F. Wagner

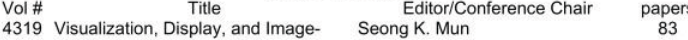
Guided Procedures Chin-Tu Chen, Anne V. Clough 62

4222 Image Proional Images PACS and Integrated Medical Information Sys: Design \& Evaluation Milan Sonka, Kenneth M. Hanson
Eliot L. Siegel, H. K. Huang EA. Kupheri, Dev P Chakrabo

4324 Image Perception and Performance E.A. Krupinski, Dev P Chakraborty
2003

Medical Imaging 2003: Physics of Medical Imaging

San Diego, CA Feb 15-20

Vol. 5030636 papers (108 in Physics) Attendance: 1073

Sponsors, Co-Sponsors \& Supporting Organizations

SPIE; AAPM; APS; CDRH; IS\&T; NEMA; RSNA; SCAR

Chairs

Martin J. Yaffe, Larry E. Antonuk

\section{Program Committee}

Katherine P. Andriole; Harrison H. Barrett; John M. Boone; Tom J. C. Bruijns: James T. Dobbins III; Michael J. Flynn; Paul R. Granfors; John Yorkston; Wei Zhao

Sessions

Imaging Physics I - John M. Boone X-Ray Detectors I - Larry E. Antonuk

CT - Paul R. Granfors

Breast Imaging I - Martin J. Yaffe

X-Ray Detectors II - Wei Zhao

Novel Imaging Methods - Harrison H. Barrett Breast Imaging II - John Yorkston

Volume Imaging - US/Tomosynthesis - Michael J. Flynn

Imaging Physics II - James T. Dobbins III

X-Ray Detectors III - Tom J. C. Bruijns

Breast Imaging III - Larry E. Antonuk

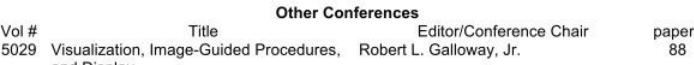

31 and Display

Systems, and Applica

Image Processing

Milan Sonka, J. Michael Fitzpatrick

geted Medical Information H. K. Huang, Osman M. Ratib

5034 Sys: Design \& Evaluation

5035 and Tech Assessment 


\section{4}

Medical Imaging 2004: Physics of Medical Imaging

San Diego, CA 14 - 19 February

Vol. 5368653 papers (102 in Physics) Attendance: 1048

Sponsors, Co-Sponsors \& Supporting Organizations

SPIE; AAPM; APS; CDRH; IS\&T; NEMA; RSNA; SCAR

\section{Chairs}

Martin J. Yaffe, Michael J. Flynn

Program Committee

Harrison H. Barrett; John M. Boone; Tom J. C. Bruijns; James T. Dobbins III Paul R. Granfors; John Yorkston; Wei Zhao

Imaging Performance - Harrison H. Barrett

Computer Tomography I - Tom J. C. Bruijns

Imaging Systems Analysis I - James T. Dobbins III

Digital Radiography I - John Yorkston

Digital Radiography II - Paul R. Granfors

Optical/US/Neutron Imaging - Harrison H. Barrett

Micro Tomography - Michael J. Flynn

Computed Tomography II - Jiang Hsie

Digital Radiography III - Wei Zhao

Imaging Systems Analysis II - Michael J. Flynn Mammography - Martin J. Yaffe

\begin{tabular}{|c|c|c|}
\hline \\
\hline Title & Editor/Conference Chair & \\
\hline $\begin{array}{l}67 \text { Visualization, Image-Guided } \\
\text { Procedures, and Display }\end{array}$ & Robert L. Galloway, Jr. & \\
\hline $\begin{array}{l}69 \text { Physiology, Function, and Structure } \\
\text { from Medical Images }\end{array}$ & Amir A. Amini, Armando Manduca & 0 \\
\hline 70 Image Proces: & J. M & \\
\hline Inform & Osmar & \\
\hline 2 Image Perception, Observer & Dev P. Chakraborty, Miguel P. & \\
\hline 73 Ultrasonic Imaging and Signal Pro & William Walker, Stanislav Emelianov & \\
\hline
\end{tabular}

\section{6}

Medical Imaging 2006: Physics of Medical Imaging

San Diego, CA 11-16 February

Vol. 6142760 papers (184 in Physics) Attendance: 1169

Sponsors, Co-Sponsors \& Supporting Organizations

SPIE; AAPM; APS; CARS; CDRH; IS\&T MIPS; NEMA; RSNA; SCAR

\section{Chairs}

Michael J. Flynn, Jiang Hsieh

Program Committee

Aldo Badano; Harrison H. Barrett; Jeffrey A. Fessler; Thomas Flohr; Robert M. Nishikawa; Michael Overdick; John A. Rowlands; Ehsan Samei; Richard L.

Van Metter; Bruce R. Whiting; Wei Zhao

\section{Sessions}

Keynote Session - Michael J. Flynn

Mammography - Robert M. Nishikawa

Tomosynthesis - Richard L. Van Metter

X-ray CT: Cardiac - Jiang Hsieh

Optical and MR Imaging - Harrison H. Barret

X-ray Imaging Detectors I \& II- John A. Rowlands / Wei Zhao

X-ray CT: Systems - Bruce R. Whiting

Innovative Imaging - Jiang Hsieh

X-ray Imaging - Michael Overdick

Dual Energy X-ray Imaging - Michael J. Flynn

Computational Simulation - Aldo Badano

CT and DR Performance Assessment - Ehsan Samei

Cone Beam Reconstruction - Jeffrey A. Fessler

CT Image Reconstruction - Thomas Flohr

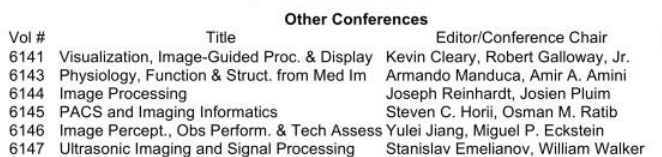


2008

Medical Imaging 2008: Physics of Medical Imaging

San Diego, CA 16-21 February

Vol. 6913788 papers (181 in Physics) Attendance: 1250

Sponsors, Co-Sponsors \& Supporting Organizations SPIE; AAPM; APS; CARS; IS\&T MIPS; RSNA; SIIM; SMI; DICOM

\section{Chairs}

Jiang Hsieh, Ehsan Samei

\section{Program Committee}

Aldo Badano; Mats E. Danielsson; Jeffrey A. Fessler; Thomas G. Flohr; Christoph Hoeschen; Hee-Joung Kim; Robert M. Nishikawa; Michael Overdick; Christoph Hoeschen; Hee-Joung Kim; Robert M. Nishikawa; Michael Overdick;
Norbert J. Pelc; John A. Rowlands; Katsuyuki Taguchi; Richard L. Van Metter;

$$
\text { Bruce R. Whiting }
$$

Sessions

Keynote and Small Animal Imaging - Jiang Hsieh; Ehsan Samei Innovative Imaging - Aldo Badano Optical and MR Imaging - Mats E. Danielsson X-ray Detectors I \& II - Michael Overdick / Bruce R. Whiting Performance Assessment and Phantoms - Ehsan Samei Dual Energy - Jiang Hsieh

Breast Tissue Modeling and Estimation - Ehsan Samei

Breast Imaging - John A. Rowlands

Cardiac Imaging - Christoph Hoeschen

CT Applications - Robert M. Nishikawa CT System Models - Norbert J. Pelc Systems and Corrections - Thomas G. Flohr Tomographic Reconstruction - Jeffrey A. Fessler Algorithms and Reconstructions - Katsuyuki Taguchi

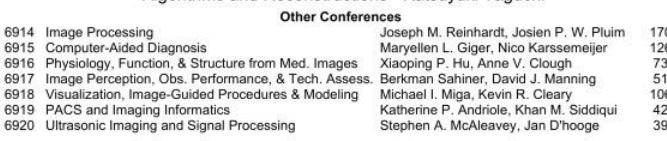

2009

Medical Imaging 2009: Physics of Medical Imaging

Lake Buena Vista, FL 9-12 February

Vol. 7258866 papers (201 in Physics) Attendance: 1107

Sponsors, Co-Sponsors \& Supporting Organizations SPIE; AAPM; APS; CARS; IS\&T MIPS; RSNA; SIIM; SMI; DICOM

Chairs

Ehsan Samei, Jiang Hsieh

\section{Program Committee}

Guang-Hong Chen; Mats E. Danielsson; Thomas G. Flohr; Stephen J. Glick; Christoph Hoeschen; Hee-Joung Kim; lacovos S. Kyprianou; Robert M. Nishikawa; Michael Overdick; Norbert Pelc; Jinyi Qi; John A Rowlands; Jeffrey

H. Siewerdsen; Katsuyuki Taguchi; Bruce R. Whiting; John Yorkston

\section{Sessions}

Keynote and CT Dose: Tribute to Bruce Hasegawa - Ehsan Samei; Jiang Hsieh

CT Performance - Ehsan Samei; Jiang Hsieh

CT Applications - Norbert J. Pelc Breast CT - John A. Rowlands

Breast Tomosynthesis - Stephen J. Glick

Nuclear Medicine - Katsuyuki Taguchi

Non-X-Ray Imaging - Hee-Joung Kim; Jinyi Q X-Ray Detectors - John Yorkston

Radiography and Mammography Performance - Christoph Hoeschen; John Rowlands

Photon-Counting and Direct-Conversion Systems - Mats E. Danielsson Tomosynthesis - Christoph Hoeschen CT Algorithms - Thomas G. Flohr CT Corrections - Jeffrey $\mathrm{H}$. Siewerdsen

CT Hot Topics - Guang-Hong Chen CT Reconstruction - Bruce R. Whiting

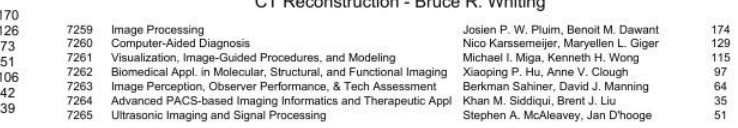

2010

Medical Imaging 2010: Physics of Medical Imaging

San Diego, CA 13-18 February

Vol. 7622811 papers (190 in Physics) Attendance: 1094

Sponsors, Co-Sponsors \& Supporting Organizations

SPIE; AAPM; APS; CARS; IS\&T MIPS; RSNA; SIIM; SMI; DICOM

Chairs

Ehsan Samei, Norbert J. Pelc

Program Committee

Guang-Hong Chen; Dianna D. Cody; Mats E. Danielsson; Thomas G. Flohr; Stephen J Glick; Michael Grass; Christoph Hoeschen; Hee-Joung Kim; lacovos S. Kyprianou; Robert M Nishikawa; Jinyi Qi; John A Rowlands; John M. Sabol; Jeffrey H. Siewerdsen; Katsuyuki Taguchi; Bruce R. Whiting; John Yorkston

Sessions

Keynote and Radiation Therapy Imaging - Ehsan Samei; Norbert J. Pelc Breast Imaging - Robert M. Nishikawa; Christoph Hoeschen Breast Tomosynthesis - Stephen J. Glick; Jeffrey H. Siewerdsen Performance Evaluation - John M. Sabol; Aldo Badano

$X$-ray Phase-Contrast Imaging - Hee-Joung Kim; Norbert J. Pelc Novel Imaging Topics - Christoph Hoeschen; Bruce R. Whiting Breast Imaging - Measurement Techniques - John Yorkston; Ehsan Samei Selenium-based Detectors - John A. Rowlands; John Yorkston Photon Counting Detectors - Mats E. Danielsson; John M. Sabol

CT Dose, Quality, and Techniques - Thomas G. Flohr; Michael Grass Detectors - Katsuyuki Taguchi; Stephen J. Glick CT Algorithms - Jinyi Qi; Guang-Hong Chen

CT: Dual Energy and Photon-counting - Dianna D. Cody, Mats E. Danielsson CT Algorithms and Compressed Sensing - Guang-Hong Chen, Bruce R. Whiting Cone Beam CT - Jeffrey H. Siewerdsen; Michael Grass

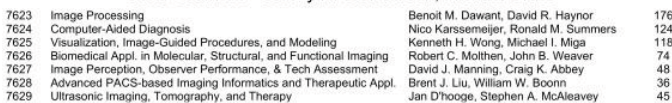




\title{
2011
}

\section{Medical Imaging 2011: Physics of Medical Imaging}

\author{
Lake Buena Vista, FL 13-17 February \\ Vol. 7961864 papers (204 in Physics) Attendance: 1136 \\ Sponsors, Co-Sponsors \& Supporting Organizations \\ SPIE; AAPM; APS; CARS; IS\&T MIPS; RSNA; SIIM; SMI; DICOM \\ Chairs \\ Norbert J. Pelc, Ehsan Samei, Robert M. Nishikawa

\section{Program Committee}

Guang-Hong Chen; Dianna Cody; Mats Danielsson; Maria Drangova; Thomas Flohr; Stephen J. Glick; Michael Grass; Christoph Hoeschen; Marc Kachelriess; Karim S. Karim; Hee-Joung Kim; Despina Kontos; lacovos Kyprianou; Jinyi Q;; John A. Rowlands; John M. Sabol; Taly Gilat Schmidt; Jeffrey H. Siewerdsen;

Katsuyuki Taguchi; Anders Tingberg; Bruce R. Whiting; John Yorkston;

\section{Sessions}

Keynote and Imaging and Health Economics - Norbert J. Pelc; Ehsan Samei

X-ray Imaging - John A. Rowlands; Christoph Hoeschen Metrology - Robert M. Nishikawa; John Yorkston

Iterative and Statistical Reconstruction - Jinyi Qi; Guang-Hong Chen

Detectors I \& II- John Yorkston; John A. Rowlands / Karim S. Karim; Mats Danielsson

Breast Imaging - Anders Tingberg; Stephen J. Glick

Tomosynthesis I: Reconstruction - John M. Sabol; Michael Grass

Tomosynthesis II - Despina Kontos; Anders Tingberg

X-ray Imaging: Phase Contrast Diffraction - Jeffrey H. Siewerdsen; Taly Gilat Schmidt Image Reconstruction - Bruce R. Whiting; Katsuyuki Taguchi

CT III: Multi-energy - Thomas G. Flohr; John M. Sabol

Novel Systems - Mats Danielsson; Taly Gilat Schmidt

CT IV: Cone Beam - Maria Drangova; Marc Kachelriess

Dose - lacovos S. Kyprianou; Hee-Joung Kim

Two Special Sessions on Dose with a Panel Discussion - Ehsan Samei; Dianna D.

Cody / Christoph Hoeschen; Michael F. McNitt-Gray / Ehsan Samei
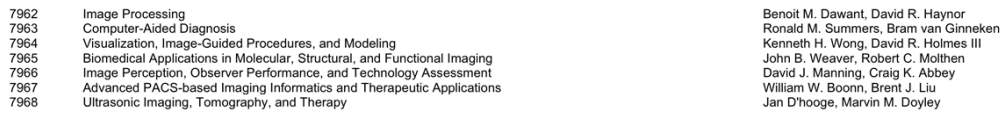


\title{
2012
}

\section{Medical Imaging 2012: Physics of Medical Imaging}

\author{
San Diego, CA Feb 5-9 \\ Vol. 8313909 papers (233 in Physics) Attendance: ? \\ Sponsors, Co-Sponsors \& Supporting Organizations \\ SPIE; AAPM; APS; CARS; MIPS; RSNA; SIIM; SMI; WMIS; DICOM \\ Chairs
}

Norbert J. Pelc, Robert M. Nishikawa, Bruce Whiting

\section{Program Committee}

Hilde Bosmans; Guang-Hong Chen; Dianna D Cody; Mats E Danielsson; Maria

Drangova; Thomas G. Flohr; Stephen J. Glick; Michael Grass; Christoph Hoeschen; Marc Kachelriess; Karim S Karim; Hee-Joung Kim; Despina Kontos; lacovos S. Kyprianou; Joseph Y Lo; Jinyi Qi; John A Rowlands; John M Sabol;

Taly G. Schmidt; Jeffrey H. Siewerdsen; Anders Tingberg; John Yorkston

\section{Sessions}

Keynote and 3D Breast Imaging - Norbert J. Pelc; Robert M. Nishikawa

3D Breast Imaging - Hilde Bosmans; Joseph Y. Lo

Breast Multi-Energy/Photon Counting - Mats E. Danielsson; Stephen J. Glick

Mammography - Anders Tingberg; Despina Kontos

X-Ray Imaging - Hee-Joung Kim; Karim S. Karim

Small Animal Imaging - John Yorkston; Maria Drangova

Photon Counting Systems and Techniques - Taly G. Schmidt; Jeffrey H. Siewerdsen

General Radiography and Fluoroscopy - John A. Rowlands; Hee-Joung Kim

Cone Beam CT - lacovos S. Kyprianou; John Yorkston

CT - Dianna D. Cody; Marc Kachelriess

CT Detection Performance - Jinyi Qi; Bruce R. Whiting

Dose - Christoph Hoeschen; Dianna D. Cody

Reconstruction I \& II -Guang-Hong Chen; Michael Grass/ Thomas Flohr; Jeff Siewerdsen

Tomosynthesis Reconstruction - John M. Sabol; lacovos S. Kyprianou

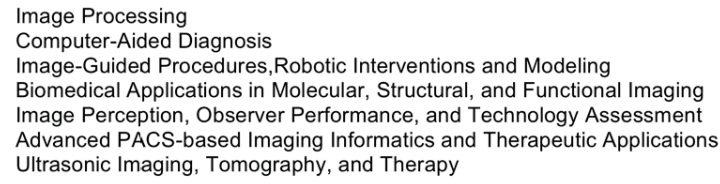




\section{Abbreviations}

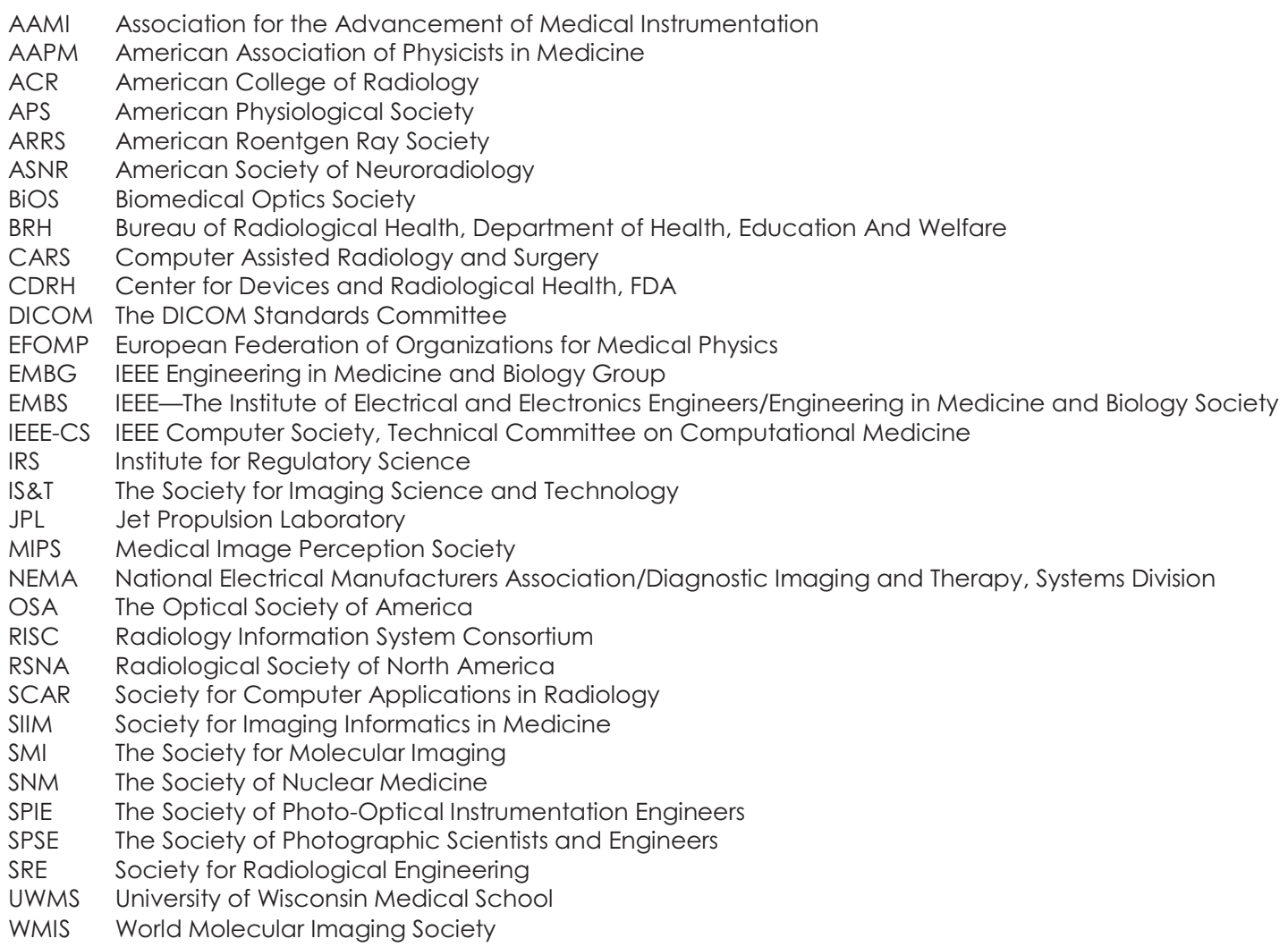

